\title{
Rahvalaulud ja rahvamuusika Virumaal
}

\begin{abstract}
Ingrid Rüütel
Teesid: Nagu eesti rahvalaulud üldse, jagunevad ka Virumaa rahvalaulud kaheks suureks ajaloolis-stiililiseks põhikihistuseks - vanemaks ehk regivärsiliseks (Soomes nimetatud tavaliselt kalevalamõõduliseks ehk runolauluks) ning uuemaks ehk lõppriimiliseks rahvalauluks. Esimene kujutab endast unikaalset kultuurinähtust, mille poeetilis-muusikaline stiil on tuntud üksnes läänemeresoome rahvastele, teised on oma vormilt ja muusikalt lähedased Euroopa rahvaste viimaste sajandite rahvalaulule. Nende vahepeale jääb väiksem rühm nn siirdevormilisi rahvalaule.

Virumaa kuulub üldisemasse Põhja-Eesti keele- ja kultuuriareaali, mis haarab ka Lääne-Eesti ja saared ning mida võib pidada eesti klassikalise muinaskultuuri hälliks. Siin hakkas kõige varem arenema püsipõllundus ning mindi üle viljelevale majandusele ja paiksele asustusele, tekkisid vanimad eesti külad ja kujunes patriarhaalne suurpere. Ilmselt just siin sündis viimasel aastatuhandel e.m.a., - läänemeresoome aluskeele hilisemas arengujärgus - regivärsiline (kalevalamõõduline) rahvalaul, mis kandus üle kogu Eesti ja levis teistegi läänemeresoome rahvaste asualadele. Põhja-Eestis arvatakse olevat tekkinud eesti regilaulu vanimad liigid, nagu lõikuslaulud, kiigelaulud, mitmed mütoloogilise alusega jutustavad laulud jm.
\end{abstract}

Märksõnad: esitustavad, rahvalaul, Virumaa

Virumaa regilauludest ja -viisidest on ilmunud trükis mitu ammendavat väljaannet: Eduard Laugaste koostatud "Vana kannel VI:1-2. Haljala regilaulud" (1989), Hilja Kokamäe, Ülo Tedre ja Edna Tuvi koostatud "Vana kannel VIII. Jõhvi ja Iisaku regilaulud" (1999) ning Ruth Mirovi ja Edna Tuvi koostatud "Vana kannel IX. Lüganuse regilaulud" (2009). Lisaks on ilmunud Ingrid Rüütli koostatud kogumikud "Ühte käivad meie hääled" I ja II, kuhu on koondatud kõik viisidega üles tähendatud Väike-Maarja, Kadrina ja Rakvere kihelkonna regilaulud ning valik uuemaid laule (Rüütel 1997; Rüütel 2001). Virumaa regilaulude näiteid koos viisidega leidub ka kogumikes "Ida-Virumaa rahvakultuurist" (Rüütel 1992) ja "Lahemaa vanad laulud" (Mirov jt 1977). Seega on 
Virumaa vanad rahvalaulud huvilistele hästi kättesaadavad ning võimalikuks saab siin enam tähelepanu pöörata nende kujundiloome alustele ja esitustavadele, lähendiks autori varem ilmunud käsitlused (Rüütel 1997: 12-24; 2001: $12-23 \mathrm{jt})$.

Regilaul tekkis ajal, mil meie esivanemate keel oli nii foneetiliselt kui ka morfoloogiliselt tänasest ja ka 19. sajandi eesti keelest küllaltki erinev. Olulised muutused on toimunud foneetikas, morfoloogias ja leksikas. Eesti keelest on kadunud paljud grammatilised vormid ja sufiksid, sõnades on toimunud siseja lõpukadu. Vanad vormid võidi lauludes asendada mingite teisendustega. Näiteks rahvalaulukeeles harilik ie-lõpuline sisseütlevas käändes tegevusnimi (-maie), mis on esinenud ka vanas kirderannikumurdes, on kujunenud varasemast vormist *-mahen (*laulamahen < laulamaie). Tavakeeles lühenes see algul kolmesilbiliseks laulama ja lõpuks kahesilbiliseks vormiks laulma, mis sellisena lauluvormi ei sobitunud. Keele arengu tõttu on meieni säilinud regilaulude väljendus palju muutunud ning värsimõõt oluliselt teisenenud. Eesti keelele iseloomulik teine välde on hilistekkeline, Põhja-Eesti rannikumurdes see puudub nagu soome keeleski. Seetõttu on ka Virumaa lauludes pika ja lühikese silbi vaheldus märksa regulaarsem kui mujal Eestis. Ka on Virumaa regivärssides kauem püsinud kõnekeelest kadunud vormid ja sõnad ning Virumaa regivärss on üldse säilitanud arhailisema kuju kui mujal. Mari Sarv oma uurimuses "Loomiseks loodud: regivärsimõõt traditsiooniprotsessis" näitab, et eesti regivärsis on aegade jooksul segunenud esialgne kvantiteedisuhetel põhinev, nn kalevalamõõduline ja hilisem silbilis-rõhuline süsteem. Keele erinevatest arengutest tingitult kujunes Eestis kolm erinevat värsimõõduala: põhjaeesti, lääne-eesti ja kagueesti. Põhja-Eesti süsteem on kõige kalevalamõõdulisem, kusjuures selle tuumalaks on just Virumaa (Sarv 2008: 130-131).

\section{Mis oli enne regilaulu?}

Tõenäoliselt olid juba siis olemas sellised arhailised žanrid, nagu mitmesuguste töödega seotud või sidepidamiseks kasutatavad hüüded ja hõiked, loodushäälte jäljendused, itkud, loitsud, äiutused, millel pole veel meloodiat tavapärases mõistes, kuid mille esitus erineb tavalisest kõnest erilise intoneerimisviisi poolest (Rüütel 1998-1999). Tekst võis koguni puududa, neid esitati kas mingil tähenduseta silbil või häälikul, või siis oli see suurel määral improviseeritud ja erines vanadest laulutekstidest ka vormilt. Virumaalt on üles tähendatud kõiki mainitud liike. Oma praktilise funktsiooni tõttu elasid nad osalt kõrvuti vanemate ja ka uuemate rahvalauludega ning mõned neist, näiteks äiutused või jahimeeste peibutushäälitsused pole kaotanud oma aktuaalsust tänapäevalgi. 
Itkudest on andmeid mitte üksnes Setumaalt, kus neid mäletatakse tänapäevani, vaid ka mujalt Eestist. Muistsete usukujutelmadega seotud itkud püsisid kauem just Ida-Eestis (Pino \& Sarv 1981: 4-6; Rüütel 2000: 289-294). Andmeid itkudest ning tekstifragmente on kirja pandud kogu Ida-Eesti alalt, Ida-Virumaalt pärineb aga ainus väljastpoolt Setumaad tehtud surnuitku viisi noodistus. See sarnaneb enam ingeri ja vepsa kui setu itkudega.

\section{Näide 1}

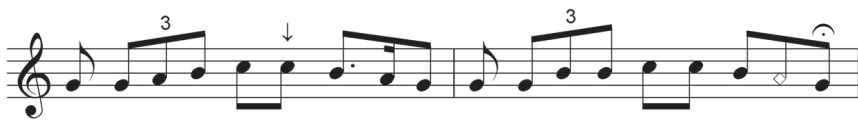

Kui ak-ka-vad ku-ked kiir-ga-ma, kui ak-ka-vad lin-nud lau-la-ma,

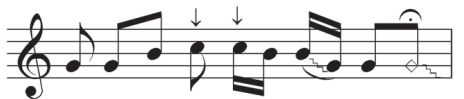

ei kuu-le mia ä-'äm siu ial-ta.

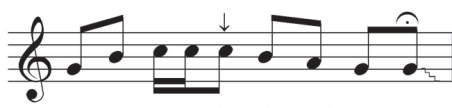

Te-gid mi-'u-le kir-jud ken-gäd...

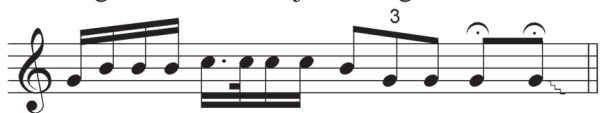

Kas sul o-li kar-tu-la või ka-pus-ta puu - du?
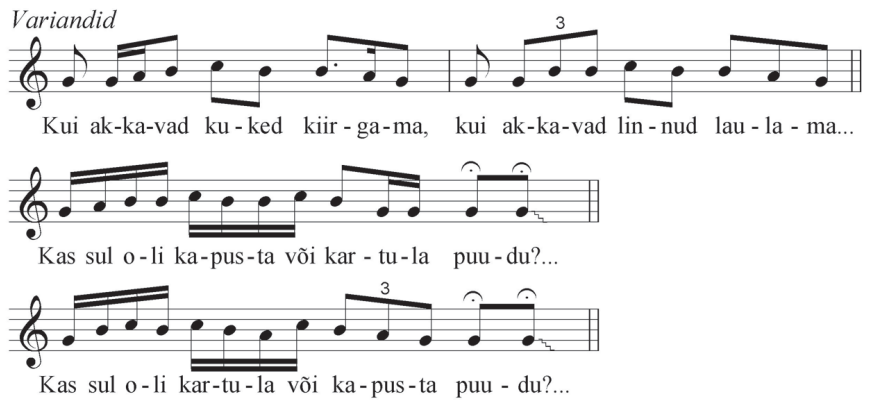

RKM II 68, 13/4 (3) < Tallinn < Virumaa - J. Ruus (Rüütel) < Lisette Siirak (1956).

Alutaguselt on andmeid ka erilistest nekrutite ärasaatmise kommetest ning nendega seotud itkudest. Itkude esitamist nimetati loetamiseks. Loetajateks olid tavaliselt naised, kuid leidus ka meesloetajaid.

Narva lähedal Eestimaa valdade elanikkude (nevakate) juures on moodiks kurva elujuhtumiste ajal loetada. Loetamine on see, kui poollauldes, poolnuttes haledad joru ühtsoodu edasi aetakse. Loetamise peale on iseäranis naesed meistrid, on aga ka ütlemata osavaid mehi leida, kes nutupilli 
löövad. Loetatakse matuste, neekruti lahkumiste ja vahest ka pulmade ajal, nimelt enne seda, kui pruut kirikusse viiakse. Nevaka naene loetab poja kaelas rippudes, kui viimane soldatiks läheb, umbes nõnda:

Kevadel, kui käud ja linnud laulavad, kui kõik pääsukesed pesa teevad, kus oled siis sina, mu pojuke, kus oled sina, mu silmaterake, oh,oh, oh,oh!

Kui tuleb see laupäne päiväke, lähevad sauna mu lapsukesed. Vaalin keikile valged särgikesed, kus kaugel on siis mu pojuke, kus on siis mu rammutuke, oh, oh, oh, oh!

(E 33672/3 Narva - J. Sirdnak (1897).)

Simunast on märgitud meloodilisi karjasehuikeid, mis olid enam tunnuslikud Lõuna-Eestile. Tõenäoliselt on traditsioon siia kandunud Kodaverest, mis oli omapäraseks kultuurisillaks Põhja- ja Lõuna-Eesti vahel.

Loodushäälenditest olid jahimeeste peibutuste kõrval populaarsed linnulaulude kunstilised jäljendused. Need olid laadilt humoristlikud. Vastavate häälikukombinatsioonide ja esituse intonatsiooniga matkiti ööbiku, pääsukese, lõokese, peoleo, metstuvi laulu, kuke kiremist jm.

Loitsudega mõjutati loodust (nt tõrjemaagilised ussi-, hundi-, tulesõnad), tõrjuti ja raviti haigusi (roosi-, nikastuse-, valusõnad, saunasõnad), edendati töötegemist (lüpsi-, võitegemise, rehepeksu, lõikuse lõpetamise sõnad jm). Võitegemise sõnu ("Kokku, kokku, koorekene") loeti või lauldi Ida-Virumaal jüripäeval lüpsikute turvutamise juures, et lehmad hästi piima annaks. Sõnadega mõjutati ka teist inimest: erilised sõnad olid saksa viha vastu, kadeduse vastu, enda üleoleku tagamiseks ("Mina laua peal, sina laua all!"), aga ka tervisesoovimiseks.

Äiutuste rütmi ja intonatsiooniga imiteeriti lapse hälli õõtsumist. Need olid kas sõnadeta või lihtsa, tihti improviseeritud tekstiga (vt nt Rüütel 1992: 254). Äiutustest kasvasid välja kindla poeetilis-muusikalise struktuuriga hällilaulud. Hüpitus- ja mängitussalme esitati rütmiliselt lugedes või retsiteerides.

Suurem osa Virumaalt üles tähendatud regivärsilistest lauludest olid tuntud ka mujal Põhja-Eestis, paljud üle kogu Eesti. Haruldasemad on sellised, mille levila piirdus üksnes Virumaa või siis Virumaa ja sellega külgnevate aladega. Rahvaluulekogud kajastavad suuremalt jaolt 19. sajandi lõpupoole ja 20. sajandi alguse (seega regilaulu taandumisperioodi) situatsiooni, mistõttu laulude arvukus ja esinemissagedus eri kihelkondades ei tarvitse vastata traditsiooni õitsenguperioodile. Viise on enam üles tähendatud Jõhvi, Haljala, Kadrina ja Väike-Maarja kihelkonnast, kus laulutraditsioon säilis ilmselt kauem. 


\section{Regilaulude liigid}

Virumaal on hästi esindatud kõik vana rahvalaulu põhiliigid - töö- ja tavandilaulud, hälli- ja lastelaulud, mängulaulud, lüroeepilised ja lüürilised laulud.

Jutustavad laulud. Piir lüüriliste ja lüroeepiliste laulude vahel eesti regilaulutraditsioonis pole alati selge. Puhtalt eepilisi laule õieti pole, sageli on tegemist mina-vormis lüüriliste jutustustega. Seetõttu on liigitamine mõneti subjektiivne ja eri uurijad on laule liigitanud erinevalt. Herbert Tampere võttis kasutusele juba Hurda aegadest käibel olnud mõiste "jutustavad laulud", mis lubab mõneti vabamat lähenemist (Tampere 1964: 3-4). Sama termini vastet (kertovat runot) on kasutanud Soome uurijad.

Mütoloogilise tagapõhjaga laulud on tekkinud siis, kui muistseid müüte veel usuti või kui need olid vähemalt veel hästi meeles. Need kuuluvad ilmselt üldse vanimate regilaulude hulka nagu ka maagilise alusega töö- ja tavandilaulud. Kosmogoonilistel müütidel põhinevaist lauludest olid populaarsed "Loomine", "Suur tamm", "Tähemõrsja". Laiemalt levinud mütoloogilistest lauludest olid Virumaal tuntud veel "Kodus käimas", "Põdratapja", "Kurg kündmas", "Täid kaladeks", "Harja otsimine", "Mõõk merest", "Kuldnaine", "Mere kündmine", "Mere pühkimine", "Laevasõit", "Kandle sünd" jt. Üksnes Virumaal ning sellega piirnevail Harju- ja Järvamaa aladel levinud "Suur härg" oli tuntud ka Soomes. Haruldasematest mütoloogilistest lauludest olid Virumaal tuntud veel "Suur saar", "Õllest saar", "Viru kosilane", "Kulla põlemine", "Oleksin Olevi", "Kala kõneleb" jt.

Kogu Eestis levinud "Ema haual" jutustab neiust, kes käib vanemate haual, paludes neil tõusta ja tulla tütrele pulmadeks veimevakka valmistama. Laul sisaldab mitmeid läänemeresoome rahvaste itkudes esinevaid motiive ja põhineb arvatavasti usul, et surnud võivad tõepoolest mõjutada elavate käekäiku ning et kontakt nendega on reaalselt võimalik. Laulu on F. R. Kreutzwald kasutanud oma eeposes ("Kalevipoeg isa haual").

Varakeskaegseid tavasid kajastavad laulud "Tütred vette" ja "Ema ei viinud vette". Samast ajast pärinevad usutavasti ka "Suisa suud" ja "Mehetapja". "Venna sõjalool" on paralleele Ida-Euroopas.

Suurem osa jutustavatest lauludest räägib perekonnaelust. Siia kuuluvad mh omapärase kompositsioonilise struktuuriga nn korduslaulud, kus neiu või noormees jutustab loo mingist õnnetusest või äpardusest, mis temaga juhtunud, seejärel läheb koju ja vestab sama loo uuesti vanematele, kes siis teda lohutavad ja annavad head nõu ("Härjad murtud", "Haned kadunud", "Tõbine naine", "Hobune varastatud", "Ehted kadunud", "Põll põrmune" jm). Korduslaulu vorm on ilmselt välja kujunenud juba kauges minevikus, ent on olnud populaarne pikema aja jooksul, mistõttu leidub eri aegadest pärinevaid laule. 
Peresuhetest jutustavad mõned perekonnaballaadid ja muud süžeelise arendusega laulud, nagu "Mehetapja", "Lunastatav neiu", "Mareta laps", "Venna sõjalugu", "Hiie noormees", "Pea piiramine", "Kaevul kosija", "Müüdud neiu", "Naise hukkaja", "Põlvist põdema", "Suisa suud" jmt. Viimane pole tähelepandav mitte üksnes oma eetiliste väärtushinnangute poolest (neiu, kes tapab oma au kaitseks, mõistetakse õigeks), vaid ka seetõttu, et see on üks väheseid laule, milles mainitakse Kalevipoega ja Sulevipoega. Arvatavasti on siin tegemist varafeodaalsete ülikutega. "Mehetapja" laulus seevastu tapab noor naine seletamatutel põhjustel oma mehe, mille mõistab hukka ka loodus - Maie palub kaitset metsapuudelt, kes aga keelduvad teda varjamast. Mujal Eestis tundmatu "Naise hukkaja" on kirja pandud vaid Lüganuse khk ja on kandunud siia ilmselt Ingerimaalt, kus see oli populaarne.

Hiliskeskaegseteks võib pidada katoliiklike kujutelmadega seotud laule "Mareta laps" (väljaspool abielu sündinud ja vanematest hüljatud laps saab jumalalt kõnevõime ja tunnistab, kes on ta vanemad) ning "Ristitud mets" (mets kuivab keelatud armusuhte tagajärjel ning hakkab taas elama pärast pühitsemist). Laulud olid tuntud peamiselt Virumaal, Järvamaal ning IdaHarjumaal. Esimese nimitegelane (Hannus, saare saksa poega) ning mitmed muud detailid viitavad sidemetele Skandinaaviamaade ja Soomega, kust laul arvatavasti pärineb.

Küla ja mõisa suhteid kajastavad "Hollandi sulane", "Sundija sulane", "Kubjas ja teomees", "Mõisa aidast varastamas", "Mõisa märg vili” jm on valdavalt meestelaulud ja sisaldavad osalt uuemaid, siirdevormilise rahvalaulu jooni. Temaatikalt keskenduvad meestele ka laulud sõjast ja nekrutist. Arvatakse, et neis võivad kajastuda sõjad 11.-18. sajandini. Sellised on "Venna sõjalugu", "Rootsi Kaarel sõdimas", "Sõjas pole matjat", "Sõjamehe haual”, "Seni hoiab hobust, kuni pea peal" jm. Viimane on haruldane ja ilmselt tekkinud Lüganuse khk (Mirov 2009: 94). Sõjaväekohustus laiendati Baltimaadele 18. sajandi lõpul (aastal 1796) ning nekrutilaulud on seega pärit põhiliselt 19. sajandist. Sõjaväeteenistus kestis algul 25 aastat, see oli eesti meestele raskeks koormaks, mis lahutas kodust, omastest ja sõpradest, hävitas nooruse ning määras tegelikult kogu nende elu. Virumaal olid tuntud laulud "Liisuvõtmine", "Nekruti püüdmine", "Nekruti põgenemine", "Sooviti soldatiks", "Asjata kasvanud - soldatiks saanud", "Põlatu soldatiks", "Soldatipõli" jm.

Omapärane jutustavate laulude alaliik on veel legendilaulud ehk piibliainelised laulud, nagu "Ori taevas" (Lüganusel hoopis Manalas), "Orja palk", "Kuue kudumine", "Maarja otsib poega". Kaks esimest on sisult mõisateemalised, viimane on vormilt ja funktsioonilt eriline, näib olevat välja kasvanud katoliiklikest või mõne muu varasema usuvoolu palvetest ning oli populaarne ka Lõuna-Eestis. 
Regilaulude temaatiline jaotus on problemaatiline, kuna samu teemasid (perekonnaelu, mõis jm) leidub erinevais laululiikides, ja teisalt põimub samades lauludes erinevaid teemasid. Reale jutustavatele lauludele leidub vasteid karjalastel, vadjalastel, isuritel ning soomlastel. Sageli võib laulu varasemaks kujuks pidada just neil säilinud versioone (näiteks "Loomislaulu" Ingeri versioon, vt Rüütel 1969). "Venna sõjalugu" on Ingeris sarnasem Ida-Euroopa prototüübile, kus hobune toob koju sõnumi tema omaniku surmast, Eestis aga arenenud omapäraselt. Kontaminatsioon laulude "Tähemõrsja" ja "Kodus käimas" süžeedest on tuntud ka vepslastel, kellelt kalevalamõõdulisi laule pole märgitud. Mordvas järgneb taevase kosilase, tavaliselt Pikse (Välgu) abiellumisele maise neiuga enamasti kodu külastamise teema (vt Kavtaskin 1963: 51-52). Motiiv on tuntud ka maridel, lõunaslaavlastel jt rahvastel.

Töö- ja tavandilaulud. Valdav osa regivärsilistest rahvalauludest on lüürilised. Vanimad on sõnamaagial põhinevad, loitsulise alusega töö- ja tavandilaulud, mis hiljem arenesid edasi lihtsalt lüürilisteks tööteemalisteks lauludeks.

Karjaselauludest olid tuntud "Söö, kari", "Kari, koju” jt. Spetsiaalseid karjaselaule on siiski vähe. Virumaal nagu mujalgi Põhja-Eestis oli kombeks külakarjusele, kes oli tavaliselt vanem mees, igast talust tüdruk või poiss abiks anda. Karjaskäimine kujunes seega noorte kokkusaamise kohaks, kus lauldi mitmesuguseid lüürilisi ja jutustavaid laule.

Rohkesti leidub lõikuslaule ("Viljad karja käia", "Lõpe lõigates", "Kaualõigatud põld", "Sirbiviskamise laul", "Lõikame vihud vägevad", "Madal vili", "Väsinud lõikaja" jmt). Lauldi ka rehepeksul ja heinatööl. Tuntud olid laulud naiste kodustest töödest. Mehed laulsid kalapüügist ja küttimisest, teekäigu- ja sõidulaule ("Kohus koju minna", "Aeg koju minna", "Hakkame, mehed, minema" jt), samuti meremeeste laule ("Tunneb tuuled nõuda", "Meremehe saatus" jt).

Vastla-, jaani-, mardi- ja kadrilaulud ning nende funktsioon oli analoogne muude eesti piirkondade lauludega. Vastla-ja jaanilaulud olid sisult maagilised sõnumised, mardilaulud aga olid arendatud pikaks laulutsükliks. Põhja-Eesti omapäraks olid martide tantsulaulud. Ka kiigelaulud olid algselt rituaalsed laulud. Hiljem, maagilise tagapõhja taandudes täienesid need rohkete lüüriliste motiividega või liitusid jutustavate looduslauludega. Kiigel käimise komme ise muutus Põhja-Eestis küla noorte kooskäimiste ja lõbutsemise tavaks, kiigelaulud aga eeskätt neidude ilulauludeks. Selliseid on Virumaalt märgitud rohkesti.

Pulmalaulud. Väga vanadeks tuleb pidada pulmalaule. Paljud neist on tuntud teistelegi läänemeresoome rahvastele ja ulatuvad ilmselt läänemeresoome ühisperioodi. Ka Mordva pulmalauludest võib leida tekstimotiive, mis on tuntud eestlastel jt läänemeresoomlastel: "Nutust järv", "Kasvatus asjata - ei tulnud tuge emale", pulmamaja tunnusmärgid (tuli toas jm), "Imetuba" (või "Neiulinn"), 
humala- ja õllelaulud (Mordvas lauldakse pulmakülaliste kostitamisel, vt Borissov 1972).

Läänemeresoome pulmakombestik lähtub sugukondlikust elukorraldusest ja selle põhialus on eelkristlik (Sarmela 1981). Eesmärgiks on kinnitada kahe suguvõsa liitu, tagada abielu õnnestumist ning valmistada noorpaari ette uueks staatuseks ja sellest tulenevateks kohustusteks. Lauludes leidub animistlikke sugemeid ("Tare teretus", "Kodu jääb tütart nutma”), oluline koht on hoiatus- ja ennetusmaagial - nutt kodust lahkumisel tagab õnneliku elu tulevases abielus. Pulmalauludes öeldakse vahel ka halba, selleks et hilisemas elus seda vältida: pruudi- ja peiupoolsete pulmalaulikute vastastikuste pilkelauludega loodeti kindlustada head läbisaamist tulevases elus jne.

Kuigi pulmakombestik oli rahvaluulekogumise aegadeks Virumaal juba taandumisjärgus, on siit siiski üles märgitud kõiki peamisi kombestikuelemente ja nende juurde kuuluvaid laule: peiupoolsete saabumine pruudikoju ja vastastikused laulud mõlema suguvõsa esmasel kohtumisel, mõrsja kodust ärasaatmine ja rituaalne nututamine, noorpaari vastuvõtt peiukodus, nõuanded ja õpetused noorpaarile, veimede jagamine, tanutamine.

Kirjeldustest ilmneb, et 19. sajandi teisel poolel olid mõnel pool, nt Kadrina khk vanad pulmakombed veel üsna elavad, kuigi muistsed usundilised rituaalid olid kaotanud oma esialgse tähenduse ja nihkunud tagaplaanile meelelahutuslike tavade ees (rahakogumised, peitmised-otsimised jms - vt Rüütel 2001, lisa). Varem tõsine toiming - mõrsjale abielunaise põlle ettesidumine, mis tähistas abielunaise staatuse omandamist, sulas kokku pulmanaljaks kujunenud nn põllelappimisega. Nooriku tantsitamine - tema esimene ametlik esitlus mehe sugulastele - muutus kohati samuti pulmanaljaks ja raha kogumise vahendiks: see toimus vahel koguni kõrtsis, kuhu pulmarong sisse põikas, ning pruudiga võisid tantsida kõik meespulmalised, kes pidid selle eest raha maksma. Traditsioonilises pulmas erilisi pulmakinke ei olnud, neid asendasid rahakogumised pruutpaarile vastavate kommete saatel.

Eesti regilaulus on lüürika teiste läänemeresoomlaste kalevalamõõduliste lauludega võrreldes tugevamini välja arendatud. Ka mõned vanad läänemeresoomlastega ühised pulmalaulud on Virumaal jm eraldunud tavandist ning hakanud elama iseseisvat elu lüürilise lauluna (vt Rüütel 1970).

Hälli- ning laste- ja mängulaulud. Kindla funktsiooni ja esitusviisiga on lastele lauldavad hällilaulud ning hüpitus- ja mängituslaulud. Lastele on lauldud ka ahellaule, millest osa on välja kasvanud astraalmütoloogilistest süžeedest ("Meri õue all”, "Neli neitsit”). Omapärase laululiigi moodustavad mõistatuslaulud. Lastelaulude hulgas on ka laule loomadest jms. Vanad hälli- ja mängituslaulud püsisid oma praktilise funktsiooni tõttu käibel kõrvuti uuemate lauludega. 
Mängulaulud ("Nõela-", "Paja-", "Kulli-", "Lamba-", "Naeri-", "Hobuse-", "Laeva-", "Kuninga-", "Nuku-" ja "Leinamäng" jmt) kuulusid noorte repertuaari (vt Mirov 1992; Mirov 1998). Hilisemad Lääne-Euroopa laululaenud "Siimumäng", "Leigarimäng", "Hanemäng" jt evivad siirdevormiliste laulude tunnuseid.

Erilist tähelepanu väärivad ristitants ja selle juurde kuuluvad laulud. Koreograafia järgi (mille kohta on andmeid ebapiisavalt) võib seda pidada mingi kadrilli tuuri erikujuks, teisalt sarnaneb see Mulgimaa telutegemiste ja leedu sutartineste esitusviisiga. Lisaks tavalistele, otse tantsu kommenteerivatele laulutekstidele on vähemalt Haljala khk nagu Mulgimaalgi ristitantsu saatel esitatud ka "Tähemõrsjat". Kõik see osutab ristitantsu hoopis vanemale algupärale.

Tavandiväline lüürika. Enamik regivärsilisi laule kuulub nn tavandivälise ehk üldise lüürika hulka, mis pole seotud kindla koha, aja ega esitusviisiga. Virumaalt on jäädvustatud hulgaliselt rikka poeetilise kujundikeelega lüürilisi laule, mis kuuluvad eesti rahvalauluklassika kaunimate näidete hulka. Valdavalt on tegemist neidude ja naiste lauludega, leidub ka meeste laule, eriti hilisemas kihistuses. Regivärsiliste meestelaulude osa Virumaal on üldse suhteliselt suurem kui Eestis tervikuna. Viimased erinevad oma laadilt ja stiililt naiselikust tundelüürikast, neis leidub enam huumorit ja satiiri.

Lüüriliste laulude hulgas on palju väga poeetilisi laule rõõmust ja murest, elust ja surmast, laulust ja laulikust, loodusest, kodust, lapsepõlvest, noorusest ja noorte suhetest, kosjadest ja abielust, lese- ja vaeslapsepõlvest. Virumaal on olnud populaarsed ka paljud orjuslaulud, mis kajastavad talupoegade ja mõisa suhteid pärisorjusaegses eesti külas ("Põrgu mõis", "Mõis rikas valla vaevast", "Orja hool", "Tilluke teopoiss", "Orjade rada", "Ikka peab ori olema", "Mõisast pääs", "Maamees toidab saksad, sandid" jpt). Ainult või peamiselt Kirde-Eestis on tuntud laulud "Orja pühapäev", "Ööd tuleme - ööd läheme", "Peksuhaavade vihtlemine", "Orja toit - umbrohi", "Kubjas, lase lõunale" jt, samuti uuem, siirdevormiliste tunnustega "Vaida mõisas vargil käisin". Hulk laule kajastab sotsiaalseid suhteid külas, kus vastanduvad pererahvas ja sulased-teenijad, rikkad ja vaesed, peretütred ja vaeslapsed.

Õlu oli muiste rituaalne jook, mida valmistati ja joodi pöördelistel hetkedel, nt suvisel ja talvisel pööriajal (mis hiljem seostusid vastavalt jaanipäeva ja jõulutega) ning pulmade ajal. Tõenäoliselt uskusid eestlased nagu mitmed muudki rahvad õllel olevat loovaid võimeid vallandav toime. Igapäevaseks joogiks muutus see alles hilisemal ajal. Kõrtsid eeskätt teeliste peatus- ja puhkepaigana levisid Eestis eriti alates 17. sajandist. Viinapõletamine mõisates kasvas aga oluliselt 18. sajandi lõpust alates ja siitpeale suurenes ka viina 
tarbimine talupoegade hulgas. Seega on viina ja joodiku teema, mida võib kohata nii bravuursetes meestelauludes kui ka naiste abielulauludes, suhteliselt hiline.

Ilmselt uuemad on ka traditsioonilise külaühiskonna lagunemisega seotud moraaliprobleemid ("Peetud neiud", "Linnast naine - ei julge koju tuua", "Kõrtsinaise ilus tütar"). Tagasihoidliku, karske ja tööka neiu ideaal on ilmselt üsna vana ("Karske neiu", "Virkuse õpetus", "Virk veimetegija", "Võta naine töölt", "Ära käi külas"). Naine, kes on eelkõige pereema, olgu terve ja töökas, puhas ja korralik ning lesele mehele minnes hoolitsegu võõraste laste nagu omade eest ("Lesele mehele”). Mehes hinnati hoolivust ja usaldusväärsust; petis, joodik, kuri ja vägivaldne mees oli naisele raske koorem.

\section{Kuidas mõista regilaulu poeetilisi kujundeid}

Vanades rahvalauludes ei väljendata oma mõtteid ja tundeid otse, vaid poeetiliste kujundite mosaiigina.

Regilaulude rikkalikes poeetilistes kujundites võib leida jälgi maagilistest vormelitest ja muistsest mütoloogilisest sümboolikast. Viimaste tähendus on tihti tuhmunud. Kuigi müüdid ja sümbolid võivad olla rahvusvahelised, on nende konkreetne laululine väljendus eesti regivärssides ainulaadne. "Lõpe, põld!", “Sirise, sirp!", “Kari, koju!”, “Söö, kari!”, “Saja, vihm!”, “Üle, vihm!”, “Tule, uni!”, paljude pulma- ja kiigelaulude imperatiivsed vormelid põhinevad sõnamaagial. Üleloomulikke võimeid omistati laulule üldse: laul langetab metsapuid, muudab mere mäeks, võib koguni sõja seisma panna. Raske on öelda, kuivõrd siin on tegemist lihtsalt poeetiliste liialduste, kuivõrd tõsiselt võetud uskumustega. Laulule ja pillimängule on maagilisi võimeid omistanud paljud rahvad.

Reas lauludes kohtab muistseid tekkemuistendilisi motiive: pisaraist sünnib järv, õllest või merepühkmeist saar. Laulus "Kannel” kajastub muinasjutusüžee kandlepuu kasvamisest ülekohtuselt surmatud vaeslapse südamest ja erinevatel Euraasia rahvastel tuntud müüt pillikeelte valmistamisest ohvrina hukatud neiu juustest, mis annab pillile maagilise võime (vt Oinas 1985). On koguni arvatud, et kandlemäng võib eemale peletada surma, näiteks tõrjuda katku (Peebo \& Peegel 1989: 127).

Viljeluseelse inimese usu aluseks oli idee inimese ja loomade surematust, taassündivast hingest. Kosmogoonilise maailmapildi keskmes oli kujutlus Põhjatähe ümber keerlevast tähistaevast. See sümboliseeris maailmakõiksuse (kosmose) turvalist korraldust, igavest ringkäiku, looduse kevadist elluärkamist, jahiloomade tagasitulekut inimeste lähedusse, kogukonna tagasipöördumist kalapüügi- ja jahipaikadesse (Sarmela 1996: 24). Ka varasema viljelusperioodi inimese ettekujutuses oli maailm ühtne ja inimene osa loodusest. Tähtsat rolli uskumustes hakkas etendama esivanematekultus. 
Muistset kosmogoonilist ja astraalmütoloogilist alust on leitud lauludes "Loomine", "Harja otsimine", "Suur tamm", "Meri oue all" ("Neli neitsit") jm. Esimeses seletatakse taevakehade teket linnumunadest, "Harja otsimine" arvatakse põhinevat päikesemüüdil, viimaste aluseks on arvatavalt kujutelm maailmasambast, millel laotub Linnutee. Mingi puu kasvamisest taevani ja selle maharaiumisest on laule paljudel rahvastel: eestlastel oli selleks tamm, mordvalastel õunapuu ja kask, Laoses liaan, Liibanonis seeder. Laul arvatakse põhinevat müüdil, mille aluseks on olnud taevapilt Linnuteest, nii nagu seda on nähtud Baabüloni piirkonnas umbes neli tuhat aastat tagasi. "Siis oli Linnutee kevadise pööripäeva ajal otse vaataja pea kohal otsekui imeline tähti täis riputatud puu, ja sügisese pööripäeva ajal keerdus see ümber silmapiiri kui taevaline meri. Vaatajale sügisel jäi mulje, nagu oleks see hiiglapuu vahepeal maha raiutud, mis võiski anda tõuke vastava müüdi loomiseks." (Oinas 1999-2004)

Laulude aluseks olevad müüdid olid tuntud paljude Euraasia rahvaste pärimuses ning ka Idamaade kõrgkultuurides. Rahvusvahelise levikuga müüdiained ise pärinevad ilmselt ajast enne regivärsivormi arvatavat teket I aastatuhandel eKr ning on poeetilise vormi saanud hiljem (vt Annist 1969: 33-42; Mirov 2009: 88), kuid usutavasti siiski juba läänemeresoome ühisperioodil, kuna olid tuntud erinevatele läänemeresoome rahvastele (Kuusi 1963: 31-80, 129-215).

Ka kiik seondub maailmasamba kujutelmaga. Kuigi eestlastel ei ole säilinud andmeid, mis lubaksid kiike käsitada kui maailmapuud või maailmasammast, on meil kiigega seotud sama atribuutika nagu neil rahvastel, kellel see on ajaloolises mälus säilinud (kiik asub maastikus kõrgemal kohal, veekogu lähedus, seos lindudega jne). Muistsele funktsioonile viitavad kiigelaulude loitsulised algusvormelid (kiigu kõrgele; kui ei kanna, siis kadugu jne). Tähelepanu väärib kiigetraditsiooni seos elu igavest uuestisündi sümboliseerivate munadega. Mäletataval ajal kinkisid tüdrukud kiigele tulles mune kiigeseppadele ja kiigutajatele noormeestele. Muiste võis siin olla tegemist ohvriandidega, eriti kui silmas pidada, et kiige juurde toodi ka kanu ja muid kodulinde (Tooge munad, tooge kanad, / tooge pardid paelakaelad, / tooge hanid lestajalad!). Kaugematel soomeugrilastel, näiteks udmurtidel on tuntud tava ohverdada kiige juures kodulinde. Ohvriandidele osutavad värsid kiike kiunub kinda'aida, / pealispuu punaseid paelu (punased paelad olid soomeugrilastel tuntud erinevais tavandeis kui varasema vereohvri asendajad - vt Richter 1982: 29; Gemujev 1990: $88,160 \mathrm{jm}$ ). Kiikumisel usuti olevat maagiline mõju viljakasvule (nagu vastlaliul linakasvule) ning tervistav mõju kiikujale. Hilisemal ajal muutus kiigel käimine ning kiigel laulmine külarahva, eriti noorte omavahelise suhtlemise ja lõbutsemise vormiks.

Uskumus, et mardid tõid viljaõnne, kadrid karjaõnne, on levinud kogu Eestis. Maskeeritud olendeis, kes sügisel talust tallu käisid, võib näha esivanemate- 
kultuse jooni. Analoogselt hingede ajal kodu külastavate esivanemate hingedega pidi neilegi toa valgeks tegema, nemadki tulid kuskilt kaugelt, teispoolsuse piiri tagant, laskusid taevast alla müstilist hõbedast õrt mööda, läbisid teistelegi rahvastele tuntud teispoolsuse takistusi, nagu märg, soine maa jne (vrd Hiiemäe 2010: 78-80). Lähedasi kujundeid kohtab näiteks mordva pulmalauludes, kuid need kuuluvad paljude rahvaste, sh balti ja slaavi rahvaste vanemais kalendrilauludes esinevate "maailmamudeli" atribuutide või universaalsete takistuste hulka, mis tuleb ületada teise ilmaga suhtlemisel (vrd Vinogradova 1982: 153-164; Laurinkienè 1984).

Ahellaulu vorm, küsimused-vastused, mõistatamine ja paljud laulumängud olid algselt maagilise funktsiooniga. Nendega loodeti tagada kosmilist harmooniat maa peal, inimeste head käekäiku, elu jätkumist aastaringide kordudes, igavest taassündi. "Leinamängule" leidub paralleele mõnede Euroopa rahvaste kalendrikommetes, kus see sümboliseeris aastaaegade vaheldumist - looduse närtsimist sügisel ja ärkamist kevadel. Ka "Nõelamängus", aga samuti teistelt Euroopa rahvastelt meile levinud "Hanemängus" ja "Väravamängus" on oletatud astraalmütoloogilist alust, iseasi, kas laulud jõudsid Eestisse koos algse tähendusega või ilma selleta.

Peale "Loomislaulu" on muidki laule, milles lindudel on eriline tähendus. Eesti mütoloogias on tuntud hingelinnu kujutelm. Kui neiu lubab minna linnuks taeva alla (Rüütel 2001: laul 203), siis ei tarvitse see olla pelk poeetiline kujund. Linnud vahendavad lauludes tihti sõnumeid omastele. Ka toovad nad surmasõnumeid (samas: laulud 174 ja 375). See põhineb uskumusel, et rändlinnud veedavad talve surnute maal.

Laulud on aja jooksul palju muutunud. Mentaliteet pole püsiv. Inimeste igavesed probleemid tõlgitsetakse ja mõtestatakse ümber üha uuesti uutes oludes; pole ka üht müüti maailma loomisest, see luuakse igas kultuuris uuesti. Suur tamm - maailmasammas - raiutakse maha agraarühiskonna inimeste elu turvaliseks muutmiseks, arutleb Matti Sarmela (1996: 25; vrd Goršič 2011). Tuleb lauliku vennake (kes võib kehastada nii venda, samaealist külapoissi kui ka abikaasat), raiub tamme, millest tehakse kõike inimestele eluks vajalikku.

Agraarühiskonna kommete ja laulude peamiseks sisuks oli karja-ja viljaõnne taotlemine. Sõnamaagial põhinevaid motiive esineb töö- ja tavandilauludes, mis ongi loitsudest välja kasvanud, loitsulised on vastlalaulude käsud ja hoiatused, mardi- ja kadrilaulude soovid ja manamised. Ka jaanitulel ning kiikumisel usuti olevat maagiline mõju viljakasvule.

Üle eesti tuntud laulus "Tähemõrsja” (“Taevased kosilased”) valib maine neiu talle kosja tulnud taevakehadest Tähe, eelistades teda kuule ja päikesele. Kuigi siingi võib olla lähtealuseks mingi muistne kosmogooniline müüt (analoogseid laule on teistelgi rahvastel, nt mordva ja ka mõnede türgi rahvaste lauludes 
abiellub neiu piksega), saab valiku tegemisel oluliseks juba agraarinimese filosoofia. Salme nimele on otsitud mitmeid seletusi. Kõige usutavam tundub, et Salme neitsi eeskujuks oli kõlalt lähedane läti Saules meitas (Päikese tütar), keda läti analoogsetes lauludes samuti kosivad Kuu ja Koidutäht (Auseklītis). Seega võib algselt tegemist olla kosmogooniliste objektide eneste vahelise abieluga (Kokare 1996: 69-71).

Mida tähendavad laulude "Imemaa" ja "Tuule tuba" fantastilised kujundid, on senini jäänud mõistatuseks. Imemaale sõutakse üle vee. Vesi on traditsiooniline teispoolsuse eraldaja ja vahendaja paljude rahvaste mütoloogias, veekogusid kaudu siirdusid näiteks lahkunute hinged teise ilma. Sõudes üle vee jõutakse maale, kus nied kuked kulda süövad, kuked kulda, kanad karda, haned haljasta hõbedat. Võimalik, et siingi on tegemist mingite astraalmütoloogiliste reliktidega. Laulus "Tuule tuba” jõutakse pika teekonna järel mingisse paika, kus taevased ilmastikunähtused (tuul, sadu, rahe, lumi, udu, pilved) on "toa teinud". "Toa" vanem tähendus on elamu, ja soome keeles tähendab väljend tuulen tupa õhulossi. Tõenäoliselt terendab sellegi kujutluspildi taga midagi enamat kui lihtsalt fantaasia. Ometi saame siingi piirduda üksnes oletustega.

Ajal, mil vanad regilaulud kirja pandi, olid muistsed usukujutelmad enamasti taandunud ja mütoloogilised sümbolid püsisid vaid kaunite poeetiliste piltidena, mis ajendasid uusi fantastilisi mõttelende. Aja jooksul muistse mütoloogilise maailmapildi kujutelmad segunevad kristlikega, tekib usundiline sünkretism. Vanad ettekujutused hakkavad taanduma, kuid püsivad mälus, uued ei ole veel täiel määral omaseks saanud. Nii võivad need põimuda ühes ja samas laulus.

Kosmose loonud linnu poegadest tekivad endiselt taevakehad, kuid mõnikord ka Maarja, sest miska lapsi ristitakse, kui pole Maariat maassa (Rüütel 2001: laul 32). Jumalalt otsitakse abi ja kaitset endale ja lähedastele, siit ilmast lahkunud emale soovitakse head paika jumala juures: Jumalale eide hinge, süda Jeesuse süleje, käed Maaria kädeje, põlved Looja põrmandale (samas: laul 405). Teisal palutakse, et jumal sirutaks sinist, poetaks punast lõnga, tõmbaks vaeslapse taevasse (samas: laulud 201 ja 237). Sinise ja punase ühendus traditsioonilises värvide sümboolikas on aga jälle muistne märk teispoolsuse piirist: "Sinise-punase parallelismi üheks allikaks on looduselamused, kusjuures sellele on omistatud usundiline tõlgendus. Vikerkaar, silmapiir, päikeseloojang (piir päeva ja öö vahel) - need nähtused on ühelt poolt visuaalselt tajutavad ja seostuvad värvielamustega. Teisalt on need elamused ka sakraalse maailma peegelduseks, sõnumiks teispoolsusest. Neid kujutelmi on nii looduses kui ka usundilises maailmapildis seostatud piiri mõistega. Sinise-punase parallelism seondub piiriga looduses ning ka pöördemomentidega inimese elus" (Jaago 1997: 66). 
Olulisimateks pöördepunktideks inimese elus on abiellumine ja surm. Nendega seotud siirderiitustes on mõndagi ühist, sest mõlemal juhul siirdub inimene ühest paigast, ühest olekust ja ühest staatusest teise. Mõlema juurde kuulub rituaalne nutt. Pulmaitkudest pole põhjaeestlastel küll otseseid andmeid, ent need olid üldised setudel, karjalastel, vadjalastel, isuritel, vepslastel, ka komidel ja mordvalastel. Mõrsja rituaalne nutt isakodust lahkumisel kuulus aga olulise komponendina ka Põhja- ja Lääne-Eesti pulmakombestikku, kusjuures sellel oli maagiline tähendus: see pidi tagama õnne ja kordaminekut tulevases abielus (Kõiva 1997: 65; Tedre 2000). Virumaalgi tuntud laulutüüpe "Pisarate veeremine" ja "Nutust järv" on peetud muistsete läänemeresoome mõrsjaitkude reliktideks (vrd Kuusi 1963: 122; 176). Otsene viide sellele on pulmalaulutüüp "Nuta!" (Rüütel 2001: laul 235).

Itkude kunagisest laiemast levikust kõneleb "setu itkude ja paljude eesti rahvalaulutüüpide meeleoluline lähedus, mitmed otsesõnu itkemisele viitavad sisulised motiivid mõnedes laulutüüpides ning küllaltki sageli ettetulevad sõnastuselt kattuvad või väga lähedased värsid setu itkudes ja Eesti muude paikkondade lauludes" (Pino \& Sarv 1981: 5). Selliste laulude hulka kuuluvad Virumaal "Kellele kurdan", "Surma sajatus", "Ema haual".

Viimane, üle kogu Eesti tuntud laul on mitmes mõttes huvitav. Siin võib leida jälgi kolmest erinevast kihistusest. "Selles on tõenäoliselt kajastusi kunagisest kombest, et vaeslapsest mõrsja käis pulmade eel surnud vanemate haual, palus neilt õnnistust, kutsus pulma ettevalmistusi tegema ning pulmapeost osa võtma" (Pino \& Sarv 1981: 6). Komme on tuntud ka teistel rahvastel. Mordva pruut itkes koidu ja eha ajal kaevu kohal, et teda võiksid kuulda surnud esivanemad (Tšuvašov 1977: 354). Palve tulla kodu külastama ning tütart tema pöördelisel hetkel abistama põhineb esivanematekultusel, usul hinge surematusse, sellesse, et esivanemad võivad pärast surma kodu külastada ning mõjutada elavate käekäiku. Rituaalsele itkemisele viitab iseloomulik mina-sina-vormiline poeetiline monoloog, millega tütar surnud ema poole pöördub, samuti laulu Virumaa variantidele iseloomulik nuturätiku motiiv laulu alguses (nuturätikud käessa, nutukirjad rätikussa). Laulu üksikute motiivide lähteallikaks olid niisiis vaeslapsest mõrsja pulmaitkud oma mütoloogilis-usundilise maailmapildiga. Hiljem itkumotiivide algne tähendus tuhmus ning sündis poeetiline laul-dialoog. Ema vastused on eri laulualadel erinevad. Ema ei saa tõusta, kuna muru on kasvand peale mulla, aruheina peale haua, sinilille peale silma, kullerkuppu peale kulmu või silmal on sinine liiva, kulmul kulu punane jms. Laul püsis paljude põlvkondade mälus poeetilise vaeslapselauluna, kuni muistsete usukujutelmade asemele tõusid kristlikud. Ema vastab hauast: Jumal su pead sugegu, kerstukaanta kinnitagu, annivakka valmistagu! Kuigi sõna jumal iseenesest on vana läänemeresoome ühissõna, mh tuntud ka maridel, ning tähistas algul 
hoopis muid jumalusi, on siin ilmselt juba tegemist sama kristliku Jumalaga, kes kõiki vaevatuid lohutab, karjalapse särgigi kuivatab (Rüütel 2001: laul 21), kes aitab vastsündinul oma vanemaid leida (samas: 318 ), kellelt palutakse abi kurjast hoidumiseks (samas: 406). Jumala sünonüümiks on Looja, paralleelvärsis esineb sageli Maarja, Jeesus on selles seoses haruldasem.

Muistsed mütoloogilised sümbolid, läänemeresoome vana rahvalaulu poeetika üks lähtealuseid, muutusid hiljem uskumusliku tagapõhja taandumisega lihtsalt kauniteks poeetilisteks kujunditeks ning täienesid regilaulu assotsiatiivsele loomeprintsiibile omaselt paljude uute kujunditega, millel ei olnud enam mingeid uskumuslikke tagamaid. "Lauldud hobu" on ilmselt fantaasiapilt, mis toetub ühelt poolt vanadele lauludele laulu loovast jõust, teiselt poolt ahellauludele iseloomulikele kompositsioonivõtetele. Hobune on meestelaulude lemmikmotiiv, olgu siis juttu tööd tegevast või lusti sõitvast noormehest.

Linnud, kellele muiste omistati erilisi võimeid, jäävad armastatud kaaslasteks ka hilisemas lüürikas. Pulmalauludes ("Sirgu jäljed") on algselt ilmselt tegemist sõnatabuga - rituaalse keeluga nimetada mõrsjat oma õige nimega nagu ka kosjakommetes. Lind on sagedane inimese, eeskätt neiu või naise poeetiline sünonüüm tavandivälises lüürikas (vt Peegel 1991: 936). Virumaa lauludes võib lind olla neiu, vaeslapse, karjase või koguni armastatud mehe võrdkujuks (“Armsama kojuootamine”). Linnud ei laula üksnes metsas, linnulaul kaunistab samuti koduümbrust (“Oma küla”, “Tore sõit”).

Puhast looduslüürikat pole just väga palju, siiski leidub mitmeid kauneid näiteid: laulutüübid "Kolm metsa", "Kolm järve”, “Õunapuu”, "Mäed täis männikuid”, "Helise, mets!", "Ladvad lindudele”, “Õhtu” jt. Poeetilisi loodusmotiive kohtab veel paljudes muudes lauludes, nii murelauludes ("Kellele kurdan", "Orja elu") kui ka rõõmsast meeleolust kantud lüürikas ("Tore sõit", "Kaasa tervitamine" jm). Loodus jääb inimesele lähedaseks ka siis, kui usk animismi (looduse hingestatusse) kaob. Kurb laulik ei kurda oma muret inimestele ega kivile kirikuteel ja paele papi välja peal, sest kivi ei mõista neiu keelta, paas ei neiu palveeida. Neiu kurdab kullerkuppudele, halab angervaksadele, nutab noorele rohule, kes lauliku murekoorma all kolletavad. Eemalviibivale abikaasale saadetakse loodusjõudude - tuule, rahe ja pilvedega terviseid ("Kaasa tervitamine").

Rohkesti on laule laulust ja laulmisest. Lauliku staatust ja laulu mõju on hinnatud kõrgeks ka siis, kui sel pole enam loodust ümberkujundavaid ja muid üleloomulikke võimeid: kogu küla ja vald tulevad kuulama laulikut, kelle laulule helisevad vastu metsad, kelle hääl kostab üle maade ja merede, kelle sõnadel pole lõppu ("Laulu võim", "Helise, mets!", "Vastulaulmine”, "Palju sõnu” jm). Populaarseks saab laulude õppimise ja laulikuks saamise teema ("Kust laulud", "Laulud tööl õpitud”, "Laulud pulmades õpitud”, "Lauliku soost” jt). Siingi leidub 
rohkesti kauneid poeetilisi kujundeid. Laulud on õpitud looduse keskel tööd tehes, lauljaanne päritud kodustelt. Laulik pole tuimade toast, ta on võrsunud lauliku soost, pillipuhuja perest, kandlelööja kambrist; laulikud olid isa ja ema, lapsekiigutaja ja väike vennake. Ema kandis teda kaasas pulmades, kus söötis lauliku käest, jootis pillipuhuja peekrist ("Laulud pulmades õpitud").

Jätkuna varasematele itkumotiividele sünnivad laulud kurvast laulikust, kes istub muremäel, hoolekaevu kaldal, muremütsike peas, hoolepõlleke ees ("Kurb laulik"). Tavaliselt ei seletata otse, mis on mure põhjuseks: mullu jõin murekarika, tunamullu hooletoobi, tänavu sõin leinaleiva... Laulus "Neiu matus" sõnastatakse kujundikeeles, kuhu ja kuidas soovitakse end lasta matta. Uuemate detailide kõrval äratavad tähelepanu väljendid tehke mul kivine kirstu, pange paasista põranda, mis nagu viitaksid muistsele kivikirstkalmele. Huvitavaid etnograafilisi ja muid tõsielulisi detaile võib leida muudeski lauludes.

"Suu laulab, süda muretseb" on tänapäevalgi kasutatav poeetiline kujund, lähtunud regilaulust "Kurb laulik". Aktuaalsena on püsinud filosoofilise alltekstiga laul "Laula, kuni elad" (selle Tõstamaa variant on kõlanud folkloorifestivali "Baltika" motolauluna Eestimaa eri paigus). Laul oli populaarne ka Virumaal, erinesid vaid viisid ja keelemurre.

Palju on laule kodust, vanematest, perekonnast, nähtuna enamasti jällegi noore neiu silmade läbi. Emaarmastusele on pühendatud südamlikke sõnu ("Memme vaev", "Millal maksan memme vaeva", "Ema arm"). Kaks esimest esinevad vadjalastel ja isuritel, kohati Eestis pulmalauludes, kust need ilmselt ongi lähtunud. Ema kiidetakse hea kasvatuse eest ("Ema hästi kasvatanud"). Muretu lapsepõlv kallite vanemate hoole all vastandub hilisemale miniapõlvele mehekodus ("Isakodus ja võorrsil", "Orja elu", "Millal orja kiidetakse", "Minia meelevald"). Lauludes kajastuvad lähedased suhted teiste kodustega - isa, õdede ja vendadega. Mainitakse suurpere liikmeid, nagu onu ja tädi, nadu ja küdi, kuid suhted viimastega pole alati just head, eriti pärast vanemate surma ja venna abiellumist ("Isa loomad võõraste käes", "Vennal külas"). Mõisaorjuse kõrval jätkus pingeid oma pereski. Kuigi sõnad orjus ja orjama seostusid enamasti mõisas teol käijaga, kes võis olla sulane või peremehe noorem vend, oli sõna ori sageli minia paralleelsõnaks ning see võis märkida mistahes käsualust - karjast, vaeslast, saunanaist. Kaunis sümboolika väljendub laulus "Orjade rada" (tuntud ka nimetuse "Kuld jälgedes" all).

"Kasvatus asjata" on ahastav etteheide, miks vanemad laulja üldse on üles kasvatanud. Murekoorem võib olla erinev - raske teenijapõli, halb mees, tihti jääb põhjus üldse märkimata. Haruldane on laul "Mutiks mättasse", kus vanemad ise on oma lapse ära põlanud.

Abielulauludes kohtab tihti kurtmist halva mehe üle. Kuid mees pole sugugi alati kuri ja joodik, vaid sageli hoopis lahke pillimees või muidu igati hea ja 
hooliv kaasa ("Hea mees"). Võib leida tõelist armastuslüürikat ("Alati meeles", "Armsama kojuootamine", "Kaasa kaugel", "Kaasa tervitamine"). Erinevatest ametimeestest valib neiu kindla elujärjega põllumehe, kes on põline rikas.

Lauludes kiidab noormees oma väljavalitut ("Oma neid"). "Must naine" on humoristlik meestelaul. Korduslaulu kompositsiooniga "Tõbine naine" jutustab noorest abielumehest, kes ei taipa oma naise näilise põdemise põhjust ning jutustab kodus vanematele oma murest. Need lohutavad teda ja õpetavad, kuidas varrudeks valmistuda.

Armastusteema kajastub ühtlasi neidude kiigelauludes. Kuu, päike, täht, vikerkaar on nüüd sagedased kujundid, millega võrreldakse kiigel kiikuva neiu ilu ja tema ehete sära ("Ilus neiu kiigel"). Lauliku eneseväärikus ja enesehinnang on üldse väga kõrged, olgu ta kas või vaeslaps ("Peretütred ja vaeslaps"). Tühja jutuga teotajale vastatakse aga uhke üleolekuga ("Laimajale").

Meestel olid omad laulud, naistel ja tüdrukutel omad, kuid kindlaid piire siin pole. Meestelaule on üles tähendatud ka naistelt ja vastupidi. Võib-olla on seegi traditsiooni taandumise tunnus. Üldiselt on naistelaulude tunneteväljendus peenem, õrnem, vaoshoitum ja lüürilisem, meestel järsem, karedam ja eepilisem. Meestelauludes on enam otseütlemist ja kiiremat sündmuste arendust, leidub erootilisi motiive ja jämekoomikat.

Naiste ja tüdrukute kohta on lauludes hulk poeetilisi sünonüüme (Peegel 1982-1989; Peegel 1991). Need pärinevad peamiselt loodusest - linnu- ja taimeriigist või ka neidude välistest tunnustest ja ehetest. Neiud on hellad ja kullad, haned, kanad, käod või pardikesed, õunaõied, kanepi- või linakiud, maja ilud ja toed. Mehele meelepärane naine on priske ja punane, sirge ja sale, valge ja valev, terve ja terane. Mehed seevastu on tihtipeale joodikud ja piitsasepad, metsapullid ja hallid sõnnid, aga ka kullad ja hõbedased, pilli- ja kiigesepad, ehitajad, laevamehed ja meresõitjad. Eriti idealiseeritakse uhkeid hobusega kihutajaid. Ratsa sõitvat noormeest võrreldakse koguni päikesega. Säravate taevakehadega võrreldakse samuti neidude ilu ja ehteid. Lauludes võib tihti kohata väljendeid hellad vennad ja õekesed hellakesed, kusjuures need ei tarvitse vanades lauludes tähendada üksnes lihaseid õdesid ja vendi, vaid ka eakaaslasi, vend märgib vahel koguni kaasat.

\section{Kus, millal ja kuidas lauldi}

Huvitavaid tähelepanekuid laulikute ja laulude esitamise ning vanade laulude taandumise kohta leidub eri kogujatel, näiteks J. Elkeni Väike-Maarja korjanduses 1915. a (EÜS XII 27/36, vt ka Rüütel 1997: 16-20). 
Juula Õun, snd 1874, Ärina külast:

Sel ajal lauleti vanu laulusid kiigel, töö juures, tee peal jm. Ärina mõisnik Moldan armastas laulusid. Kui töö tehtud, riistad pestud jne, kästi kõik tüdrukud kiigele minna. "Tüdrukud laulma ja saksad kuulama!” Kiiged olid mõisa õues, Ärinal, Altkõrtsi juures, praeguse kooli kohal, kõrtsi juures ja mujal. Lauldi ka mardis ja kadris käies. [---] Mõisast anti kadridele viina, kuli rukkeid ja muud kraami ja siis peeti nädalapäevad "kadripidu”. Enne aga sai mõisast järele kuulatud, kas lubatakse vastu võtta. Pidu aegadel olid rehepeksud seisus. Koosoleku paik oli Metsakülas Kõrtsi Hansul, ainult üks kord oli Reinu rahval, sest seal ei olnud nii hea olla. Pidulisteks olid kõik teomehed ja vaimud koos. Pidudel tantsiti, lauleti ja mängiti ringmängusid "Riia linna väravas", "Prits prilla" jt. [---] Kes lese mehele läks, sellele lauldi "Seda sa, uba, ootid". Mänguriistadeks oli torupill ja viiul. Torupilliks oli looma magu. Selle küljes oli üks puhumise toru. Kaks pulka olid, kus sõrmlikku löödi, kummalgi pulgal oli viis auku sõrmede jaoks. Uudami Kustase isa Hindrik oli torupillimängija kõrtsis. Pulmas ja pidudel pandi torupillile paelad ja kingid külge. Torupilliga mängiti tantsutükke, aga ikka nii ilusasti ei saanud kui va viiuli Villem oma viiuliga. Tantsiti viru valtsi: "Hüpake, karake, küll põrgus põlete!" Rahvalaulud kadusid, kui enam "vaimus" ei käidud ja asemele tulid koolilaulud. Vahest pahandati ka vana laulude üle, "siis hakkasime kiuste pärast pahandajatele kohaseid sõimulaulusid laulma, mille läbi mõnikord riid tuli." Kiigelaulusid lauldi kiige taktis [---], fermate juures nii kaua venitada, nagu kiige käik seda nõuab.

Jaan Abednegu, 99 a, Assamalla külast:

Vaimud (s.o mõisas orjajad tüdrukud) laulsid tee peal käies, kiigel ja pühade ajal. Mehed laulsid kõrtsis. Kiik oli külavainul. Tüdrukud laulsid vastastikku kiigel: ühes ääres öeldi ette, teises ääres lauldi vastu. Perenaesed lastega käisid ka kuulamas. Jumalasõnalaulusid ei aetud suuremat taga. Kruusimäe Tõnikse Leen oli hea laulja ja alustaja. Lauljad olid enamaste noored, ja vanad laulsid ka, kui pea "soe" oli. [---] Jaanitulel, Tammikus, põlesid tõrvaankrud ja märsid. Toodi ja joodi viina, lauleti ja mängiti ringmängusid. [---] Pulmades tantsiti ja pillid hü̈̈dsid. Pillideks olid viiul ja lõõtsapill. Kõrtsi Hansul oli ka torupill [---] koera magu. Torupillil oli üks puhumise toru, üks jäme ja üks peenike toru. Neljas oli sõrmilise toru. Torul oli roost või hanesulest keel sees, mis ei lähe lotsi. Torupilliga puhuti vana- ja uutmoodi tantsulugusid. Vanal tantsul ei olnud midagi kunsti, võta teise ümbert kinni ja löö aga vedamise moodi jalga üles ja teist maha. Viru magedat ja vananaiste valtsi ka tantsiti. 
Viiulid olid nagu praegu kolme keelega. Kannel oli nagu nü̈̈dki kannel (või tsimmel), teraskeeled peal, 15-16 tükki. Mänguriistu pruugiti pulmas, mardi- ja kadripidudel. Vahel käisime Inju mõisas märdisandiks. Pulmas oli pruudi poolt andevakk andeid täis ja need jägati pulmade lõpul pulmalistele ära. Mardisandiks käies laulsime "Marti tuleb küüniksesta", vahel laulsime "Reielist must riieldie". [---] Koolide siginemisega kadusivad vanad rahvalaulud, sest õpetati laulusi teise usu sisse. Vanu laulusi kutsuti roguviisi (regivärsi) lauludeks. Rahvas pidas lauljatest hästi lugu.

Mari Reinold, 78 a, Ebaverest:

Töölt tulles laulsid vaimud ja teomehed ikka vana rahva viisisid, kuna pulmas jumalasõnaviisisid lauldi, aga kõik ilma maksuta. Kiigel lauldi üks ees, teised tagajärele. Üle 50 aasta eest elas Määri mõisas torupillimees Peeter, see tegi torupillisid ja teisi pillisid. Torupill oli elaja maost tehtud ja kolme napatsiga, sellega puhus Peeter ilusaid lugusid ja lõi sõrmulisi, mille saatel tantsiti. Viiul oli ilus kuulda. Karja Pääro mängis ilusaid sarvelugusid.

Miina Kull, 63 a, elanud Avispeal ja Põdrangu Jätikul:

Vanu rahvalaulusid on heal meelel kuuldud. Kui naesed leikuse ajal laulsid: "Vii üle vihmahoogu!", siis jäid nooremad imestades kuulama: "Need on vanaaegsed laulud!" Muidu olid uuemad kolme- ja kahehäälelised laulud pruugis, milles naesterahvad heledasti tenorid laulsid. Mihkel Johanson tegi sikusarvest sarve, puhus sellega ilusad lood ja lõi ise sõrmulisi.

Pääru Kippar, Kaarma küla sepp (68 a) meenutas, et kiigel lauldi:

"Tulge kiigele, külanaesed, tooge munad, tooge kanad" jne. Kes kiigele tahtis minna neiude seast, see pidi muna tooma kiigemeistrile palgaks. Toodi mune ka 5-10 viisi, pandi kiige juure aukudesse nagu pesadesse, kust siis poisid nad ära võtsid. Nii lunastati kiigelkäimise õigus. Igal peretüdrukul oli peres ka oma erakana, kellest omale mune võis saada ja ka "kiigeseppadele" viia. Kiigel laulmas olid ühed eeslauljad, teised kordasid järele, kuda kiik alla vajus ja üles tõusis. Noored laulsid kiigel isekeskis rahvalaulusid, oli kuulajaid ehk mitte. Kirikulaulusid ei lauldud.

Pillidest olid olemas kolme keelega mollpillid ja suupillid (parmupillid - I. R.). Suupilli oskan ise ka teha. Torupillil oli 2-3 pulka, ühe küljes olid sõrmilised (augud); pill ise oli põiest või maost tehtud. Kõrtsides, pulmades ja kiige juures tantsiti torupilli ja harmooniku järele viru valtsi. Ringmängusi mängiti kiige juures, lagedal ja pidudel õuedes. Pidudel 
lauleti ka vanarahva laulusid ja rahvas kuulas neid heal meelel. Mõned läksid ise laulma pidule ja halvaks ei pannud seda keegi. Kiik oli Kaarma mõisa küüni taga, seal käidi pühapä ôhtuti laulmas ja mängimas. Ka oitsilised laulsid vanarahva laulusid.

19. sajandi lõpus lauldi niisiis vanu regilaule töö juures, eriti mõisas, õitsil, teel käies, pidudel, pulmades, jaanitulel, mardis ja kadris, tüdrukud laulsid ka kiigel, mehed kõrtsis. Kiigel lauldi kiigerütmis eeslaulja ja kooriga: Tüdrukud laulsid vastastikku kiigel: ühes ääres öeldi ette, teises ääres lauldi vastu. Pidudel lauldi, tehti ringmänge ja tantsiti pillide (torupilli, viiuli) saatel. Väärib tähelepanu, et siin võisid kohtuda erinevad stiilid: vanad regilaulud, torupillil mängitavad labajalalood kui ka uuemad ringmängulaulud. Huvitavad on tähelepanekud vanade laulude kadumise ning uuemate käibeletuleku kohta. Vanade laulude laulmisse suhtuti seega veel 19. sajandi lõpus enamasti tunnustavalt, kuigi tuli ette halvustavat suhtumist. Rahvalaulud kadusid, kui enam vaimus ei käidud ja asemele tulid koolilaulud. Koolide tekkega kadusid vanad rahvalaulud, sest õpetati laulusi teise usu sisse. Kuigi vahel lauldi ja kuulati meelsasti vanu laule, said populaarseks uuemad kahe- ja kolmehäälsed laulud. Kiikede kadumise põhjuseks võis mõnel pool olla ka mõisnik, kes ei lubanud oma maa peale kiikesid ehitada (Mirov 2009: 99).

\section{Regivärsiliste rahvalaulude muusika}

Vanimad lauluviisid sündisid ilmselt koos regivärsivormiga. Need olid ühe värsirea pikkused, kitsa heliulatusega, kõneintonatsioonil põhinevad, laskuva üldsuunaga polüfunktsionaalsed üldviisid, mida lauldi erinevate tekstidega, kusjuures eri lauludes kui ka sama laulu kestel võidi viisi nii meloodiliselt kui ka rütmiliselt sõnadele vastavalt varieerida. Laiemalt levinud meloodiatüüpide kõrval on ka haruldasi, mida kohtab vaid Virumaal (vt ka Rüütel 1981: 26 jj, tabel 8).

\section{Näide 2. Lõikuslaul}

EÜS II 757 (138).mus

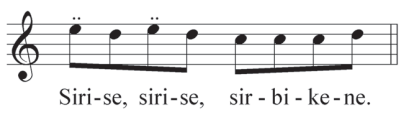

EÜS II 757 (138) < Jõhvi khk - P. Penna < Mari Krasmann (1905). 
Esineb nii mažoorset kui ka minoorset tertsi, mis võivad vahelduda ka sama viisi eri variantides. Ka erinevaid rütmitüüpe võib leida sama viisi variantides. Põhirütmi (A) kõrval esineb pikendusi rea lõpunoodil (harva kahel lõpunoodil) või igal 4. ja 8. silpnoodil:

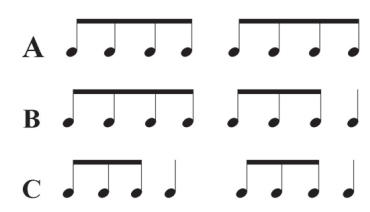

Sagedane on rütmitüüp $\mathrm{D}$, mis mujal tuleb ette peamiselt hälli- ja kiigelauludes, Virumaal aga ka pulmalauludes jm, kus liikumisrütm pole primaarne:

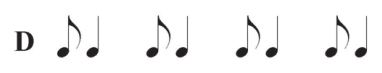

Kiigelauludes esitati lühike noot hooandmisel, iga pikka nooti venitati aga vastavalt kiige õõtsumise rütmile. Selle lõppu lisatud meloodilised kaunistused valmistasid ette järgnevat hooandmist: “... igas taktis õieti üks toon on, mis just kiige lennu ajal kinni peetakse, kuna teistest toonidest kergesti üle minnakse: nad on nagu üleviidud toonid järgneva peatooni peale, niisama nagu kiige liikumiseski a ja b õieti nagu ettevalmistused järgneva lennu vastu on.” (Rüütel 2001: 132)

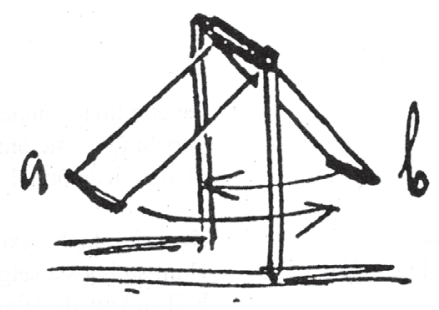

Joonis 1 .

\section{Näide 3. Kiigelaul}

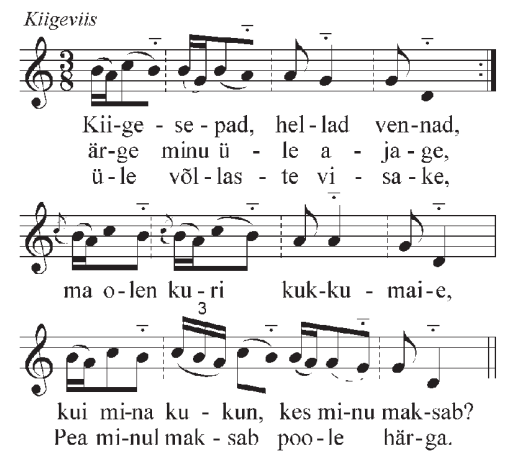

EÜS X 2535 (83) < Kadrina khk - K. Viljak < Anu Treidek (1913). 
Virumaal nagu mujalgi Ida-Eestis, samuti Ingerimaal võib kohata järgmist rütmitüüpi

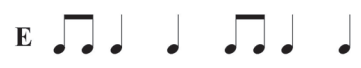

aeglastes, lüürilistes viisides, kuna uuemas traditsioonis seostub sama rütm eelkõige tantsulauludega:

\section{Näide 4.}

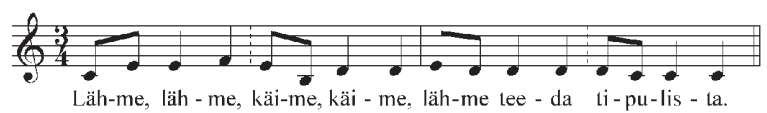

EÜS VII 1407 (20) < Lüganuse khk - O. Köstner < Miili Randmer (1905). Haruldane on järgmine rütmitüüp, mis oli levinud peamiselt Kagu-Eestis ja Ingerimaal:

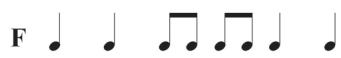

Domineerivad kahe värsirea pikkused meloodiad, kus teine viisirida varieerib esimese meloodialiikumist (vorm $\mathrm{A} \mathrm{A}_{1}$ ) või arendab seda edasi (AB). Viimasel juhul on enamasti ka heliulatus laiem, ulatudes kvindi või sekstini, millele võib altpoolt liituda subsekund või subkvart.

3silbiliste sõnade puhul tuleb nii ühe- kui kaherealistes viisides (v.a kiigelauludes) ette sõnarõhkude markeerimist, kusjuures rütmimuutustega võib kaasneda ka muudatusi meloodias:

\section{Näide 5.}

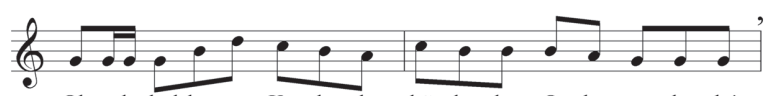

Oh seda kul-las - ta Ko-lu-da, hõ - be-dast O - he - pa - lu - da!

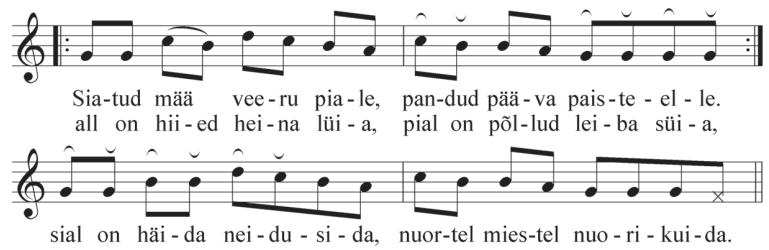

RKM, Mgn. II 1557 d < Kadrina khk - H. ja E. Tampere < Elisabeth Vari (1969). 
On iseloomulik, et põhiastme funktsiooni võib samas viisitüübis täita kas 1. või 2. aste, kusjuures selline funktsioonimuutus võib toimuda koguni viisi kordamisel sama laulu kestel. Vastavalt sellele omandab sama meloodia kas mažoorse või minoorse värvingu. Mažoorist-minoorist kui helilaadisüsteemist nende viiside puhul veel rääkida ei saa, nad esindavad varasemat muusikalise arengu staadiumi.

Näide 6.

EÜS VII $2167(185)$

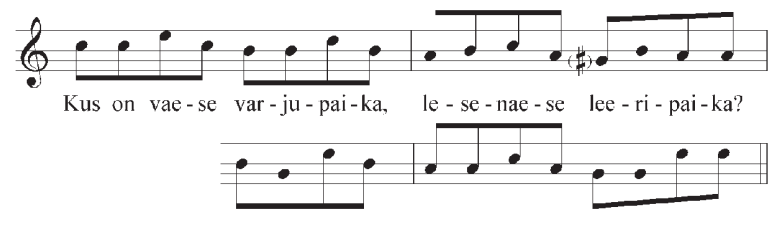

EÜS VII 2167 (185) < Väike-Maarja khk - P. Penna < Peeter Tiitsmann (1910).

Lauldi tavaliselt eeslaulja ja kooriga, kes liitus eeslauljaga rea lõpus ja kordas värssi sama või muudetud meloodiaga. Kiigelaule võidi laulda kahe kooriga. Hällilaule lauldi üksi. Nii võidi laulda ka lüürilisi, samuti muid laule, eriti regilaulu leviku hilisemas staadiumis. Kuid arvestades paljude lüüriliste laulude väga isiklikku temaatikat, võib uskuda, et üksi laulmine oli tavaline varemgi. Mardi- ja kadrilaule esitati tavaliselt koos, ilma eeslauljata.

Regilaulude hilisemal levikuperioodil olid regilauludes mõnel määral käibel neljarealised viisid, kas kaherealiste edasiarendused või uuematest lauludest laenatud meloodiad.

Täpsemaid ülevaateid Virumaa regiviiside tüpoloogiast vt "Vana kandle" Haljala, Jõhvi ja Iisaku ning Lüganuse köidetest (Kolk 1989: 50-69; Tuvi 1999: 1205-1208; Tuvi 2009). Siit selgub ka, et meestel olid vahel omad eriviisid (vt ka näide 6).

\section{Uuemad rahvalaulud}

Hiljemalt 18. sajandil hakkas regilaulu kõrvale tekkima nn siirdevormilisi laule, milles vana laulu põhitunnused - alliteratsioon (sõnade algushäälikute sarnasus) ja parallelism (mõttekordus) - polnud enam järjekindlad ning pika ja lühikese silbi vaheldusel põhinev kvantiteeruv värsimõõt asendus silprõhulisega, kuid ka lõppriim puudus või esines ebajärjekindlalt. Üheks vanimaks siirdevormiliste 
laulude rühmaks olid tantsulaulud, mida lauldi torupillilugudest pärinevail kolmeosalise taktimõõdu ja erilise rütmiga meloodiatel, nn labajalavalsiviisidel ("Hiir hüppas” jpt). Samadel viisidel lauldi siirdevormilisi mängu- ja lastelaule.

Näide 7.

EÜS VII 242 (59)

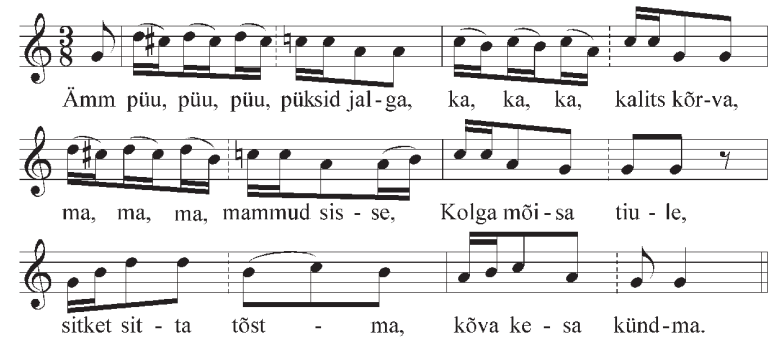

EÜS VII 242 (59) < Kadrina khk - Joh. Sõster < Madli Sõster (18961910).

Üldse võib eristada viis erinevat siirdevormilise rahvalaulu vormitüüpi, mis seondusid erinevate laululiikidega (vt Rüütel 1971).

19. sajandi teisel poolel ja 20. sajandi alguses domineerima pääsenud lõppriimiline salmilaul kujunes naaberrahvaste rahvalaulude, eriti aga saksa rahvalike laulude, kooli-, koori- ja kirikulaulude eeskujul.

Riimilise rahvalaulu eneseväljendus on palju avatum, otsesem ja ekspressiivsem. Piir lüüriliste ja jutustavate laulude vahel on uuemas rahvalauluski ebamäärane, kuid siin domineerib jutustav alge. Meestelaulu osakaal on suurem kui vanas laulus, olgu siis tegemist kas sotsiaalse sisu ja ajaloolise temaatikaga lauludega (sõja- ja sõdurilaulud, ajaloosündmuste kajastused, sulase- ja moonakalaulud jms) või humoristlike lauludega kohalikest inimestest ja külasündmustest. Viimastes kajastus vahel linnaolustik ("Rakverest kui Narva sõitsin, uhke vabrik vastu paistis...”).

\section{Näide 8.}

RKM II 68, 9/10 (1)

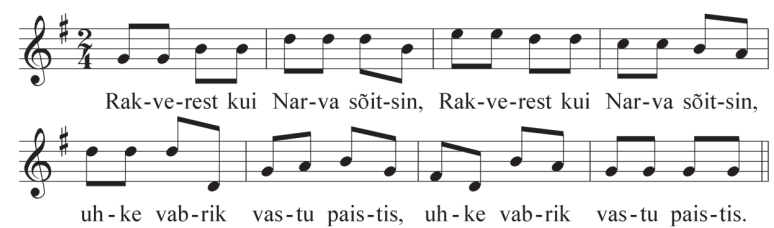

RKM II 68, 9/10 (1) < Tallinn < Virumaa - I. Ruus (Rüütel) < Lisette Siirak (1956). 
Ajalooliste sündmuste kajastused esindasid enamasti laiemalt levinud repertuaari, kuid oli ka kohalikest oludest võrsunud laule. "Seal Jõhvi mõisa ümbruses olid kohutavad lood...” kõneleb sellest, kuidas 1905.-1907. a revolutsioonile järgnenud karistussalkade tegevust kasutati isiklike arvete õiendamiseks. Uued laulude "kangelased" on varas, röövel, vang.

Virumaal nagu mujalgi Eestis olid populaarsed saksa väikekodanlikust rahvalike laulude repertuaarist pärit ja nende eeskujul loodud sentimentaalsed laulud ja ballaadid (“Kloostri neiu” jpt - vt Rüütel 1971). Suurem osa nende tekstidest levis populaarsete trükitud laulikute kaudu. On ka vanade ballaadide uusi versioone: "Siidilipp ja hõbepurjed" arendab regivärsilise ballaadi "Venna otsija" temaatikat, "Lilla istus vangitornis" on "Lunastatava neiu" uus versioon. Mõlemad tõlgiti hiljem iseseisvalt ja olid kasutusel ringmängulauludena (Rüütel 1983).

Uuematest laulumängudest olid Virumaal tuntud nii dramaatilise tegevusega ringmängud, milles etendati laulu tekstis kajastuvat sündmustikku, kui ka vahetantsuga ringmängud. Vahetantsuga ringmängudes vaheldusid aeglased laulusalmid hoogsate tantsuviisidega, mida lükiti üksikute laulusalmide vahele. Vahetantsudeks oli algul labajalg, hiljem polka, reinlender või valss.

Oli tuntud ka laiemalt Ida-Eestis esinev struktuuritüüp, kus refrääniosa moodustas viisi teine pool, mida esitati poole lühemates rütmiüksustes ("Ketra, Liisu", "Vares, vaga linnukene" jt). Mainitud laulude sünnipaigaks võib olla just Virumaa, kuigi nad olid tuntud mujalgi. Tegemist on õieti siirdevormiliste lauludega.

\section{Näide 9.}

EÜS VI 894 (93)

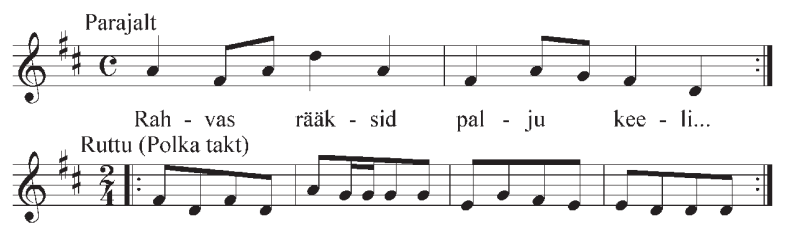

EÜS VI 894 ( 93) < Jõhvi khk - P. Penna < Juuli Õunapuu (1905).

19. sajandil levinud etendusmängude hulgas on rohkesti saksa keelest tõlgitud või nende eeskujul loodud armastus- ja kosjateemalisi laule, sh sentimentaalseid laule ja ballaade. Neis kajastuvad ka sotsiaalsed suhted. Talupojamiljööd asendab tihti mõisaolustik ja -tegelaskond.

Ka vanu regilaule kohandati ringmängudeks. Need jaotusid uuemate viisidega seostatult stroofidesse ning regivärsijoonte kõrvale sugenes uuemaid vormitunnuseid ("Hallitanud poiss", "Vares vaga linnukene”, "Kupja kolm tütart”). 
Uuemaid tegevusega laulumänge eristab vanemaist muuhulgas see, et laul saadab kogu mängutegevust ning viimane vastab laulu sõnadele, kuna vanades mängudes esineb laul tavaliselt vaid ekspositsiooni või vahepalana (dialoog-laul) ning tegevus, mis lõpeb enamasti mingi sportliku puändiga, toimub laulust eraldi (vanematest ja uuematest laulumängudest lähemalt vt Mirov 1998). Mõned etendusmängud muutusid hiljem vahetantsuga ringmängudeks. Viimased levisid peamiselt 19. sajandi teisel poolel ja 20. sajandi alguses ning tõrjusid tagaplaanile muud lõbustusvormid, taandudes lõpuks ise uuemate paaristantsude ees, mida tantsiti pilli, eeskätt lõõtspilli saatel (näiteid Virumaa ringmängulauludest vt Rüütel 1980; Rüütel 1983).

Kodu, vanemad ja lapsed on kestvalt aktuaalne teema, kuid laulude stiil ja laad on regilauludest sootuks erinev. Koduteema on enam seotud kodust (sõtta, vangi) lahkuma sunnitud või ka elumerele õnne otsima läinud noormehe mõtetega (vt nt Rüütel 2001: laulud 18, 26, 48, 49). Uuemate laulude kaunimate näidete hulka kuuluvad sõduri- ja meremehelaulud, mis on osalt suulise, osalt kirjandusliku algupäraga. 19. sajandi lõpus ja 20. sajandi alguses oli sõjaväeteenistuse aeg küll lühenenud, kuid kroonuteenistus viis tihti juba otse lahinguväljale, mistõttu sõja- ja sõdurilaulud said üheks uuema laulutraditsiooni meelisteemaks. Eesti sõjamehe traagiline surm kaugel kodust ja omastest on motiiv, mis kordub erinevate sõdade ajast pärit lauludes. Lüürilisi sõdurilaule armastasid laulda samuti naised ja tüdrukud. Väga populaarsed olid näiteks Peeter Jakobsoni üle Eesti tuntud "Eesti sõduri surm Bulgaarias" ja Inglise luuleklassiku G. G. Byroni luuletuse mugandus "Jää terveks, mu kodurand", mis Eestis oli tuntud ka sõdurilauluna (vt Rüütel 1997: 238-239).

Kui vanemais lauludes domineerivad naiste ja neidude laulud, siis uuemais on meestelaulu osa märksa suurem. Kuigi naised laulsid ka meestelaule, sealhulgas sõdurilaule, jäid nende pärisosaks ringmängu- ja armastuslaulud.

Riimiliste laulude viisid on stroofilise ehitusega, nelja või enama värsirea pikkused, avara helidiapasooniga, funktsionaal-harmoonilise alusega meloodiad, mis tuginevad mažoori või minoori põhiastmete kolmkõladele. Lauldi ka mitmehäälselt, kuigi domineeris ühehäälne laul. Ülekaalus on mažoorsed viisid. Meestelauludes kohtab nii regivärsilistele meestelauludele lähedasi jutustava iseloomuga viise kui ka uuematest pillilugudest laenatud tantsuviise. Võidi laulda ka pilli saatel. Sõdurilauludes, samuti lauludes sotsiaalsetest suhetest leidub lüürilisemaid meloodiaid. (Näiteid Virumaa uuematest lauludest vt Rüütel 1997: 223 jj; Rüütel 2001: 229 jj).

Virumaa uuemates viisides, eriti refräänides ilmneb ka vene mõjusid: 
Näide 10.

RKM II 68, 11/12 (2)

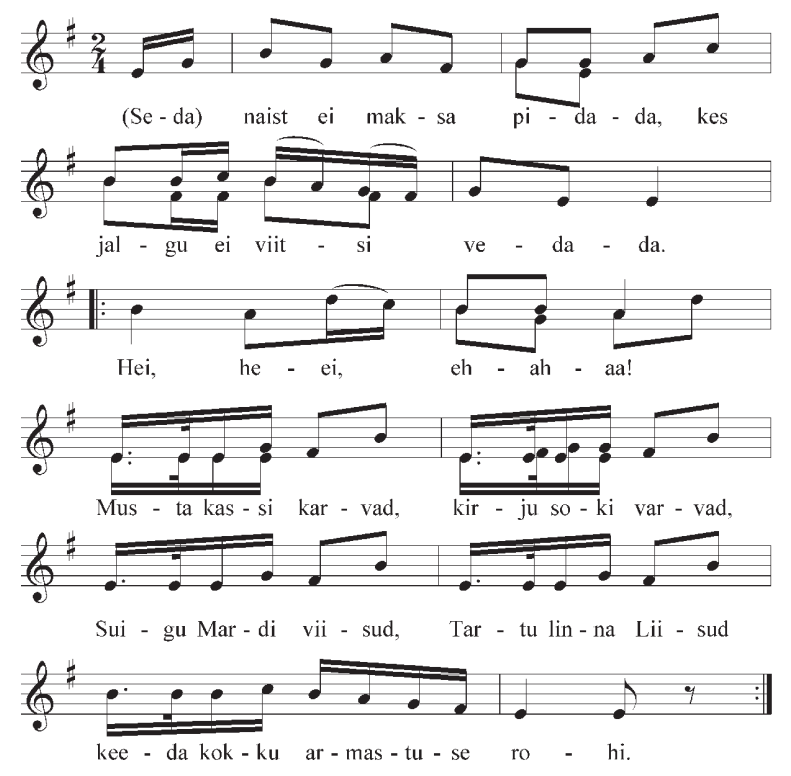

NB! Kahele poole noodisabad näitavad variante.

RKM II 68, 11/2 (2) < Tallinn < Virumaa - I. Ruus (Rüütel) < Lisette Siirak (1956).

Vanemad rahvalaulud kuulusid talupojakultuuri. Kuigi uuemad laulud said mõjusid ka mõisatest, mõjutas neid koolide ja kirjanduse kaudu linnakultuur, mis koos muude uuemate nähtustega levis maale. Teiselt poolt tõid maalt linna siirdunud linna kaasa uuemaid rahvalaule. Linna- ja maakultuur hakkasid eestlastest linnaelanikkonna kasvades sarnanema, samuti hakkas eesti kultuur hoogsalt lähenema Lääne-Euroopa kultuurile. Suur osa uue maitse kujundamisel oli kirjasõnal. Uuemate laulude sõnad võeti sageli trükitud allikatest, neid kirjutati ümber käsikirjalistesse laulukladedesse, kust nad kandusid omakorda edasi ümberkirjutustena jne. Viisid levisid suuliselt. Neid saadi teistelt rahvastelt ja uuematest pillilugudest, teisendati, arendati edasi ning loodi juurde uusi. Seetõttu pole rahvalaulu ja rahvaliku laulu piir jäik, see on suuresti interpretatsiooni küsimus. Ka uuemad laulud levisid üldjuhul anonüümselt.

Uuemad laulud olid moes, meeldisid nende meloodilisemad viisid, aktuaalne temaatika ja aktiivsem väljenduslaad. Poeetilise vormi puudused ei paistnud häirivat. Riimid olid eelkõige kõrvale, mitte silmale, nagu märkis Friedebert Tuglas. Nad olid oma aja kajastus, esindades üht etappi meie kultuuriloos, milles ei ilmne mitte üksnes uuema kunstluule ja võõraste kultuuride mõjud, 
vaid ka rahva sotsiaalpsühholoogilised muutused. "Vanem rahvalaul oleks ka siis oma vormi muutnud, kui uuem kunstluule sugugi tema kulul oma võidukäiku ei oleks alanud. See teekond naiselikust lüürikast meheliku eepika poole, mille aluseks mõtlemise viisi materjalistliseks ja konkreetiliseks muutumine oli [---], algas juba sel ajal rahva hinges, kui kunstlüürika veel liiga nõrk oli, et endist luulet ära lämmatada.” (Tuglas 1912: 56)

\section{Rahvamuusika tänapäeval}

Tänapäeval on rahvalaulu ja rahvamuusika peamiseks kandjaks harrastusrühmad: lauluansamblid, tantsurühmad, pilliansamblid. Kui pillimäng on püsinud kauem järjepidevas traditsioonis, täites seltskondlikel üritustel tantsumuusika rolli ning mõningaid uuemaid laule lauldakse tänaseni seltskonnalauluna, siis regivärsilisi rahvalaule on taaselustatud vaid sekundaartraditsioonina. Neid õpitakse ülestähenduste kaudu ning esitatakse folkloorifestivalidel (Viru Säru, Kirde Killad, Baltica, lastepidu Porkuni Pillar) ja muudel kaasaegsetel pidustustel uues kontekstis ja uues funktsioonis. 1986. a toimunud Viru Säru oli esimene rahvusvaheline autentse folkloori festival Eestis, mille algataja ja peakorraldaja oli Maie Orav. Alates 6. särust 1995. aastal kuni 2008. aastani juhtis Viru Säru festivale Igor Tõnurist. Koos sellega elavnes Virumaal märgatavalt kohaliku autentse folkloori harrastus.

Teenekad regilauluansamblid Virumaal on Lahemaa Rahvamuusikud (juhendaja Viivi Voorand), Tink-Tingadi (juhendaja Kai Tingas), Kadrina Kadrid (juhendaja Kadri Mägi), neist uuem rühm on Iisaku Regilauljad (juhendaja Pille Nagel). Virumaa uuemaid meestelaule on harrastanud Viru-Nigula Mehed. Lahemaa Rahvamuusikute, Tarvanpää Seltsi ja Kadride juures on ka rahvapilliansamblid. Lisaks on tegutsenud erinevad noodist rahvamuusika seadeid mängivad kapellid ja orkestrid.

Rahvalaule ja pillimängu on harrastatud ka Virumaa koolides. Oma kaastöös esseede võistlusele "Kuidas olla eestlane 21. sajandil” kirjutas Jõhvi Gümnaasiumi õpilane Liis Proode 2001. aastal: "Me pole tavaline rahvas tavalisel maal. Seda on märganud ka meie kooli külastanud rootsi ja saksa õpilased. Oleme erilised, paistame kõikjal silma oma isamaa-armastuse ja rahvalaulu- ning -tantsulembelisusega. Mul on hea meel, et suutsime neile näidata eestlaste eestlust ning kummutada kuulujutud, et Ida-Virumaa on kehvem, venelikum ülejäänud Eestist, Euroopast. Aga võib-olla just need eelarvamused ongi Jõhvi noori meie rahvuskultuuri viljelema pannud. Tean, et maailma parim tunne on laulda Eesti rahvalaule, tantsida Eesti rahvatantsu välismaal ning tunda aplausi südamega.” (Rüütel 2008: 97) 


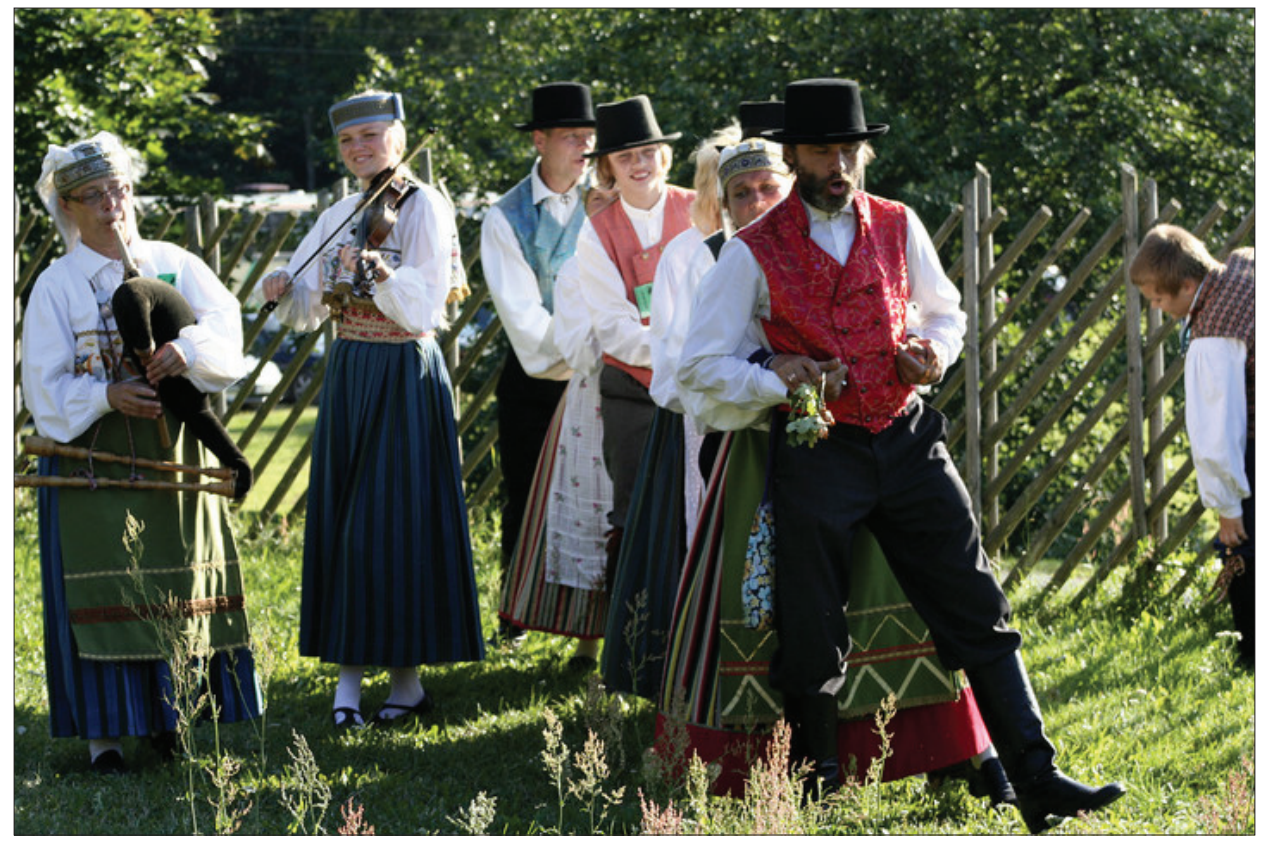

Foto 1. Esineb ansambel Lahemaa Rahvamuusikud.

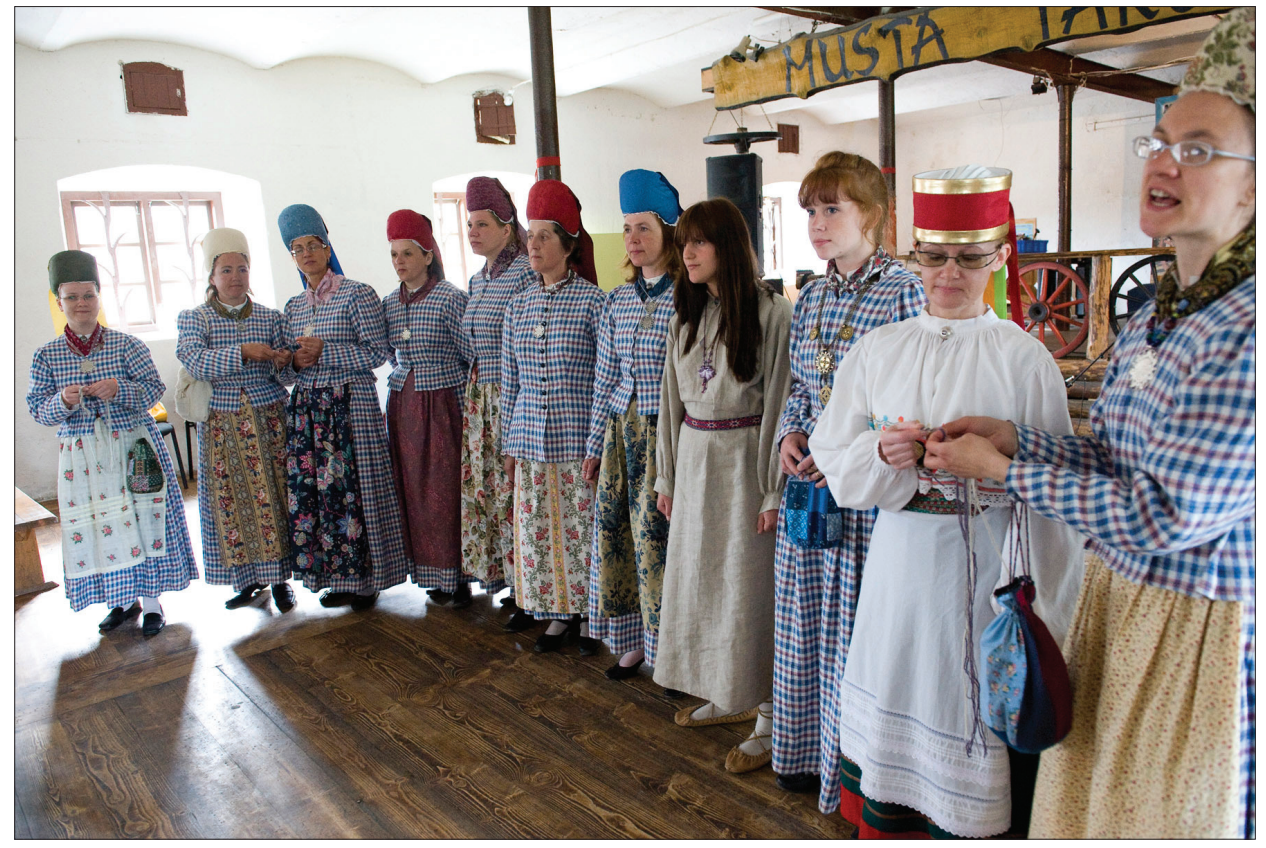

Foto 2. Kadrina Kadrid Jänedal raha särul. Avo Seidelbergi foto 2008. 


\section{Lõpetuseks}

Viimastel aastatel on hoogustunud uute, kaasaegsete regivärsside loomine. Kuigi vormipuhtus jätab neis sageli soovida, on need ometi reaalseks tõenduseks regivärsi elujõust. Tähelepanuväärne ettevõtmine oli virulaste sünnipäevakink Eesti Vabariigi 90. aastapäevaks - ajakirjaniku ja kauaaegse Tarvanpää tantsija Rein Siku algatatud ja paljude eesti inimeste ühisloominguna valminud regivärsiline lugulaul "Viru regi". 650 inimest saatsid kokku umbes kuus ja pool tuhat värsirida, toimkond eesotsas Viivi Voorannaga valis neist sobivad, täiendas omalt poolt ning liitis tervikuks. Värsse lihvida aitas ka Igor Tõnurist koos käesoleva ülevaate autoriga. Laul kanti esmakordselt ette 24 . veebruaril 2008 Rakvere Kolmainu kirikus mitme eeslaulja eestütlemisel ja kirikutäie rahva kaasalaulmisel. Üritusest on avaldatud ka DVD koos tekstivihikuga.

Omapärane muusikakujundus oli Maie Orava ja Tarvanpää Seltsi korraldusel 2010. aastal Rakveres toimunud 2. meeste tantsupeol "Elementaalne" (muusikajuht Peep Pihlak, tema abi Kadri Mägi). Tantsude saatemuusikana kasutati mh mitmeid peo tarbeks spetsiaalselt loodud regilauluseadeid, mille esitajad olid nii rahvamuusikud (Kadri Mägi, Tink-Tingadi, Kuusalu poisid, Oort) kui ka tuntud popartistid, nagu Vaiko Eplik.

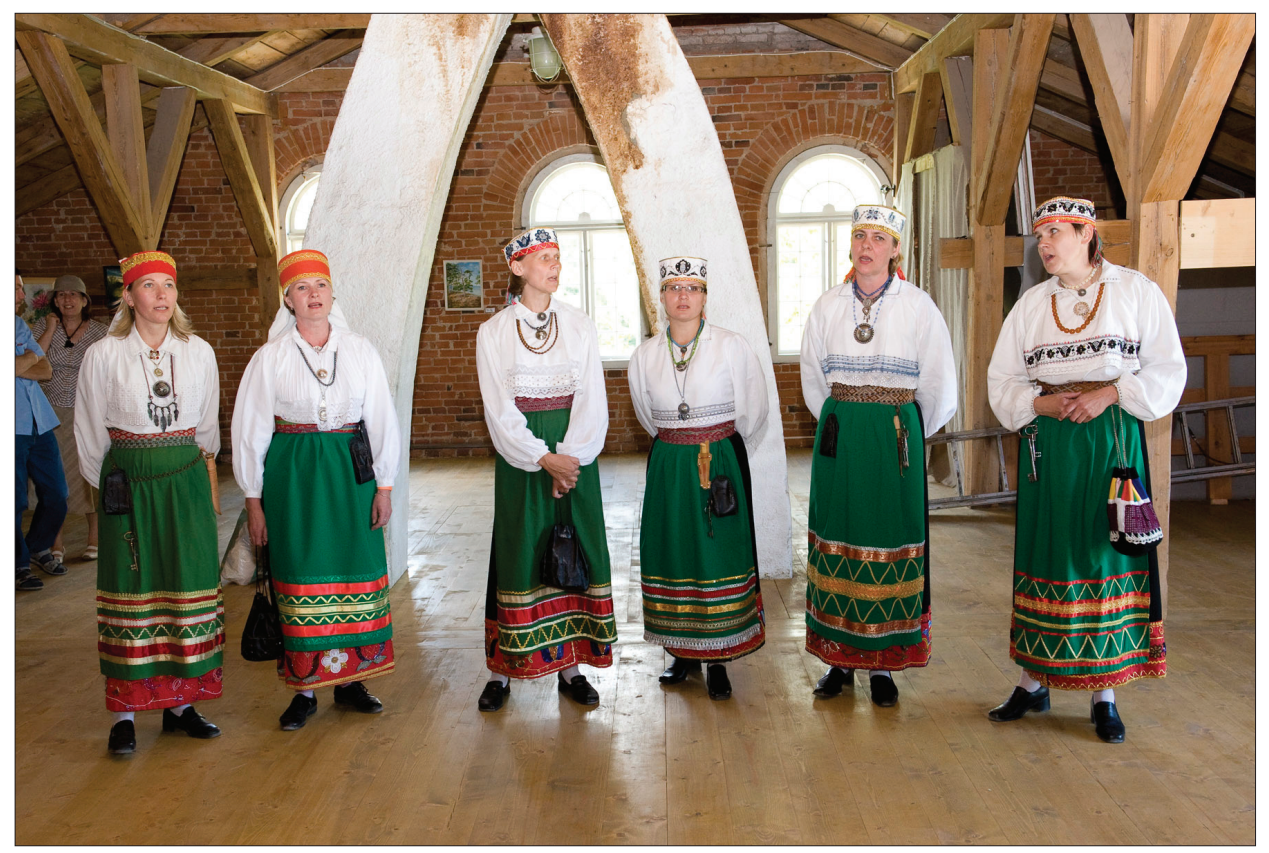

Foto 3. Regivärsilise rahvalaulu ansambel Tink-Tingadi. 


\section{Kirjandus}

Annist, August 1969. "Kalevala” kui kunstiteos. Tallinn: Eesti Raamat.

Borissov 1972 = Borisov, A. G. Ustno-poeticheskoe tvorchestvo mordovskogo naroda. Tom shestoi. Chast' pervaia. Erzianskaia svadebnaia poeziia. Saransk: Mordovskoe knizhnoe izdatel'stvo.

Gemujev $1990=$ Gemuev, I[zmail] N. Mirovozzrenie mansi. Dom i kosmos. Novosibirsk: Nauka.

Goršič, Matej 2011. "Suure tamme” laul - süntees. Mäetagused 48. Hüperajakiri. Tartu, lk 111-126 (http://www.folklore.ee/tagused/nr48/gorshitsh.pdf, doi: 10.7592/MT2011.48. gorshitsh).

Hiiemäe, Mall 2010. Kosmogoonilise ajakäsituse ilminguid regilauludes. Pühad ja argised ajad rahvakalendris. Tallinn: Varrak.

Jaago, Tiiu 1997. Mis sealt tõuseb, soost sinine, / soost sinine, maast punane? Sinise ja punase võimalikust tähendusest regilaulus. Mäetagused 5 . Hüperajakiri. Tartu, lk 54-72 (http://haldjas.folklore.ee/tagused, doi: 10.7592/MT1997.05.tiiu).

Kavtaskin 1963 = Kavtas'kin, L. S. Ustno-poeticheskoe tvorchestvo mordovskogo naroda. Tom pervyi. Epicheskie i liro-epicheskie pesni. Saransk: Mordovskoe knizhnoe izdatel'stvo.

Kokare, Elza 1996. A Survey of the Basic Structures in Latvian Mythology. Kuutma, Kristin \& Kõiva, Mare \& Sauka, Leonardas (toim). Journal of the Baltic Institute of Folklore 1/1. Baltic Institute of Folklore, lk 65-91 (http://www.folklore.ee/rl/pubte/ee/ bif/bif1/sisu.html - 21. märts 2017).

Kolk, Udo 1989. Haljala regiviiside tüpoloogia. Laugaste, Eduard (koost). Vana kannel VI:1. Haljala regilaulud. Tallinn: Eesti Raamat, lk 45-69.

Kuusi, Matti 1963. Suomen kirjallisuus I. Kirjoittamaton kirjallisuus. Helsinki: Otava.

Kõiva, Ottilie 1997. Kihnu pulmalaulutraditsioonist ja pulmakommetest. Kõiva, Ottilie \& Rüütel, Ingrid (koost, toim). Vana kannel VII:1. Kihnu regilaulud. Pulmalaulud. Tartu: Eesti Keele Instituut, lk 57-71.

Laugaste, Eduard 1977. Eesti rahvaluule. Tallinn: Valgus.

Laurinkienè 1984 = Laurinkiene, Niele I. Semantika i poetika litovskikh kalendarnykh pesen. Vil'nius.

Mirov jt 1977 = Mirov, Ruth \& Rüütel, Ingrid \& Tormis, Veljo. Lahemaa vanad laulud . Tallinn: Eesti Raamat.

Mirov, Ruth 1992. Lastemängud Ida-Virumaal. Ida-Virumaa rahvakultuurist. Tallinn: Virumaa Fond, Eesti Teaduste Akadeemia Keele ja Kirjanduse Instituudi folkloristikaosakond, lk 148-175.

Mirov, Ruth 1998. Regivärsilise ekspositsioonlauluga voormängud. Tüpoloogia, struktuur, poeetika. Eesti Keele Instituudi toimetised 2. Tallinn: Eesti Keele Instituut. 
Mirov, Ruth 2009. Lüganuse regilaulud. Mirov, Ruth \& Tuvi, Edna (koost). Vana kannel IX. Lüganuse regilaulud. Tartu: Eesti Kirjandusmuuseum, lk 85-108.

Oinas, Felix 1999-2004. Eesti rahvaluulest. Uurimusi Kalevipojast. Võrgumonograafia. Tartu (http://www.folklore.ee/rl/folkte/myte/kalev2/ - 21. märts 2017).

Oinas, Felix 1985. Kandle müütiline algupära. Uurimusi Kalevipojast. Võrgumonograafia. Tartu 1999-2004 (http://www.folklore.ee/rl/folkte/myte/kalev2/ - 21. märts 2017).

Peebo, Kadri \& Peegel, Juhan 1989. Igal puul oma juur. Murdetekste Jakob Hurda kogust. Tallinn: Eesti Raamat.

Peegel, Juhan 1982-1989. Nimisõna poeetilised sünonü̈̈mid eesti regivärssides. Sõnastik 1-4. Tallinn: Eesti Raamat; 5. Täiendused. Registrid. Errata. Eesti Teaduste Akadeemia Emakeele Seltsi toimetised 15. Tartu: Eesti Teaduste Akadeemia.

Pino, Veera \& Sarv, Vaike 1981. Setu surnuitkud. I, vihik 1. Ars Musicae Popularis. Tallinn: Eesti NSV Teaduste Akadeemia Keele ja Kirjanduse Instituut.

Richter, Elisabet 1982. Mõningaid arhailisi jooni setu matusekommetes. Linnus, Jüri (koost). Läänemeresoomlaste etnokultuuri küsimusi. Tallinn: Valgus, lk 96-100.

Rüütel, Ingrid 1969. Muistne "Loomislaul" eesti uuemas rahvatraditsioonis. Paar sammukest eesti kirjanduse uurimise teed VI. Tartu: Eesti Raamat, lk 102-132.

Rüütel, Ingrid 1970. Vadja pulmalauludest ja nende suhetest eesti laulutraditsiooniga. Linnus, Jüri (toim). Läänemeresoomlaste rahvakultuurist. Tallinn: Valgus, lk 64-93.

Rüütel, Ingrid 1971. Eesti uuema rahvalaulu varasemast arengujärgust. Paar sammukest eesti kirjanduse uurimise teed VII. Tartu: Eesti Raamat, lk 11-100.

Rüütel, Ingrid 1980. Eesti uuemad laulumängud I. Tallinn: Eesti Raamat.

Rüütel, Ingrid 1981. Typology of Estonian runo-tunes: experiment and some results. Preprint KKI 18. Tallinn: Academy of Sciences of the Estonian S.S.R. Division of Social Sciences.

Rüütel, Ingrid 1983. Eesti uuemad laulumängud II. Tallinn: Eesti Raamat.

Rüütel, Ingrid 1992. "Ei saa tõusta toonelasta..." (rahvalaul ja -muusika Ida-Virumaal 20. sajandi alguses). Rüütel, Ingrid (koost). Ida-Virumaa rahvakultuurist. Virumaa fond, Eesti Teaduste Akadeemia Keele ja Kirjanduse Instituudi folkloristikaosakond. Tallinn: Infotrükk, lk 207-258.

Rüütel, Ingrid 1997. Ühte käivad meie hääled I. Eesti rahvalaule Väike-Maarja kihelkonnast. Eesti Keele Instituudi folkloristika osakond. Tallinn.

Rüütel, Ingrid 1998-1999. Varafolkloorsetest vokaalžanridest lauluni 1-3. Mäetagused. Hüperajakiri. 1998 nr 8, lk 80-95 (doi: 10.7592/MT1998.08.ing); 1999 nr 9, lk 92-128 (doi: 10.7592/MT1999.09.rtl); nr 10, lk 90-105 (doi:10.7592/MT1999.10.rtl).

Rüütel, Ingrid 2000. Lõunavepsa surnuitkuviisid läänemeresoome itku- ja laulutraditsiooni kontekstis. Salve, Kristi \& Kõiva, Mare \& Tedre, Ülo (toim). Tagasipöördumatus: sõnad ja hääl. Tartu: Eesti Kirjandusmuuseum, lk 283-296. Sama: Rüütel, Ingrid 2010. Muutudes endaks jääda. Valik meenutusi, artikleid, uurimusi. Tallinn: TEA kirjastus, lk 155-165. 
Rüütel, Ingrid 2001. Ühte käivad meie hääled II. Eesti rahvalaule Kadrina ja Rakvere kihelkonnast. Tartu: Eesti Kirjandusmuuseum.

Rüütel, Ingrid 2008. Noored ja rahvamuusika 21. sajandil (esseekonkursi materjalide põhjal). Paar sammukest XXIV. Eesti Kirjandusmuuseumi aastaraamat 2007. Tartu: Eesti Kirjandusmuuseumi Teaduskirjastus, lk 87-112.

Sarmela, Matti (toim) 1981. Pohjolan häät. Tietolipas 85. Helsinki: Suomalaisen Kirjallisuuden Seura.

Sarmela, Matti 1996. Suomalainen eurooppalainen. Laaksonen, Pekka \& Mettomäki, Sirkka-Liisa (toim). Olkaamme siis suomalaisia. Kalevalaseuran vuosikirja 75/76. Helsinki: Suomalaisen Kirjallisuuden Seura, lk 16-34.

Sarv, Mari 2008. Loomiseks loodud: regivärsimõõt traditsiooniprotsessis. Eesti Rahvaluule Arhiivi toimetused 26. Tartu: Eesti Kirjandusmuuseumi Teaduskirjastus.

Tampere, Herbert 1964. Eesti rahvalaule viisidega IV. Tallinn: Eesti Raamat.

Tampere, Herbert 1975. Eesti rahvapillid ja rahvatantsud. Tallinn: Eesti Raamat.

Tedre, Ülo 2000. Itku relikte eesti pulmakombestikus. Salve, Kristi \& Kõiva, Mare \& Tedre, Ülo (toim). Tagasipöördumatus. Sõnad ja hääl. Tartu: Eesti Kirjandusmuuseum, lk 228-237.

Tšuvašov, Mihhail Ivanovitš 1977. Ersamordva itkud. Rüütel, Ingrid (koost, toim). Soome-ugri rahvaste muusikapärandist. Tallinn: Eesti Raamat, lk 353-384.

Tuglas, Friedebert 1912. Kirjanduslik stiil. Mõned leheküljed salmi ja proosa ajaloost. Noor-Eesti IV, lk 55-65.

Tuvi, Edna 1999. Jõhvi ja Iisaku regiviisid. Viisitüüpide loend. Kokamägi, Hilja \& Tedre, Ülo \& Tuvi, Edna (koost). Vana kannel VIII. Jõhvi ja Iisaku regilaulud. Tartu: Eesti Keele Instituut: Eesti Kirjandusmuuseum, Eesti Rahvaluule Arhiiv, lk 117-124; 1205-1208.

Tuvi, Edna 2009. Ülevaade Lüganuse regiviisidest. Viisitüüpide loend. Mirov, Ruth \& Tuvi, Edna (koost). Vana kannel IX. Lüganuse regilaulud. Tartu: Eesti Kirjandusmuuseum, lk 109-119; 832-835.

Vana kannel VI = Laugaste, Eduard (koost) 1989. Vana kannel VI. Haljala regilaulud. 1, 2. Tallinn: Eesti Raamat.

Vana kannel VIII = Kokamägi, Hilja \& Tedre, Ülo \& Tuvi, Edna (koost) 1999. Vana kannel VIII. Jõhvi ja Iisaku regilaulud. Tartu: Eesti Keele Instituut: Eesti Kirjandusmuuseum, Eesti Rahvaluule Arhiiv.

Vana kannel IX = Mirov, Ruth \& Tuvi, Edna (koost) 2009. Vana kannel IX. Lüganuse regilaulud. Tartu: Eesti Kirjandusmuuseum.

Vinogradova 1982 = Vinogradova, L[iudmila] N. Zimniaia kalendarnaia poeziia zapadnykh i vostochnykh slavian. Genesis i tipologiia koliadovaniia. Moskva: Nauka.

Ingrid Rüütel - Eesti Rahvaluule Arhiivi vanemteadur, rahvamuusika uurimissektori rajaja ja kauaaegne juht.

ingrid.rüütel@vpk.ee 


\title{
Summary
}

\section{Folk songs and folk music in Virumaa}

\author{
Ingrid Rüütel
}

Keywords: folk song, performance traditions, Virumaa

The article discusses folk songs in Virumaa region, starting from their earliest forms until today. Like Estonian folk songs in general, folk songs in Virumaa are also divided into two main historic-stylistic layers: the ancient or runo verse (in Finland usually called Kalevala-metric or runosong) and the newer or end-rhymed folk songs. The former is a unique cultural phenomenon, the poetic-musical style of which is known only at Baltic-Finnic peoples, whereas the latter, by their form and music, are close to the folk songs of European peoples in the past few centuries. Between the two, there is a smaller group of so-called transitional folk songs.

Virumaa region is part of the northern Estonian linguistic and cultural area, which also covers western Estonia and the islands, and which can be regarded as the cradle of ancient classical Estonian culture. This was the region of the earliest permanent farming as well as transfer to cultivating economy, which brought about sedentary settlement, the formation of the oldest Estonian villages and patriarchal extended family. It was probably here that in the last millennium B.C. - in the later development stage of the Proto-Baltic-Finnic language - the (Kalevala-metric) runo verse folk song was born, which spread all over Estonia and also to other Baltic-Finnic peoples. The oldest types of Estonian runosong (regilaul) are thought to have emerged in northern Estonia.

Connection with the historical tradition of the region has persisted until today. In recent years the creation of new modern runosongs has gained impetus. Although the purity of form often leaves to be desired, they are a living proof of the vitality of the runo verse.

Ingrid Rüütel is Senior Research Fellow at the Folklore Archives of the Estonian Literary Museum, founder of the research unit of folk music and its long-term leader.

ingrid.rüütel@vpk.ee 